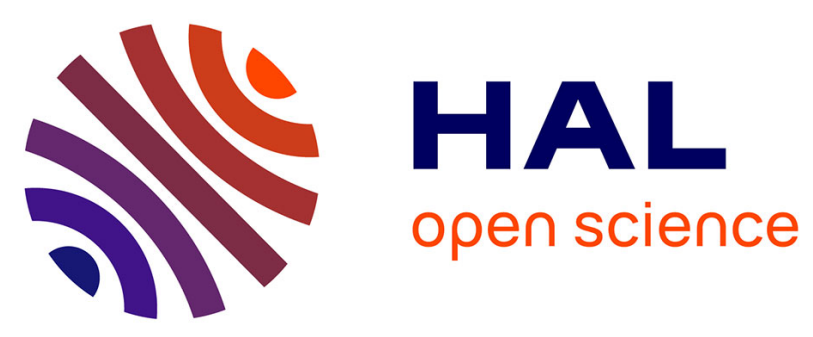

\title{
Sources and spatial distribution of dissolved aliphatic and polycyclic aromatic hydrocarbons in surface coastal waters of the Gulf of Gabès (Tunisia, Southern Mediterranean Sea)
}

Rania Fourati, Marc Tedetti, Catherine Guigue, Madeleine Goutx, Nicole Garcia, Hatem Zaghden, Sami Sayadi, Boubaker Elleuch

\section{To cite this version:}

Rania Fourati, Marc Tedetti, Catherine Guigue, Madeleine Goutx, Nicole Garcia, et al.. Sources and spatial distribution of dissolved aliphatic and polycyclic aromatic hydrocarbons in surface coastal waters of the Gulf of Gabès (Tunisia, Southern Mediterranean Sea). Progress in Oceanography, 2018, 163, pp.232-247. 10.1016/j.pocean.2017.02.001 . hal-01847666

\section{HAL Id: hal-01847666 https://hal.science/hal-01847666}

Submitted on 23 Jul 2018

HAL is a multi-disciplinary open access archive for the deposit and dissemination of scientific research documents, whether they are published or not. The documents may come from teaching and research institutions in France or abroad, or from public or private research centers.
L'archive ouverte pluridisciplinaire HAL, est destinée au dépôt et à la diffusion de documents scientifiques de niveau recherche, publiés ou non, émanant des établissements d'enseignement et de recherche français ou étrangers, des laboratoires publics ou privés. 
1 Sources and spatial distribution of dissolved aliphatic and polycyclic aromatic

2 hydrocarbons in surface coastal waters of the Gulf of Gabès (Tunisia, Southern

3 Mediterranean Sea)

4

$5 \quad$ Rania Fourati $^{1}$, Marc Tedetti $^{2 *}$, Catherine Guigue ${ }^{2}$, Madeleine Goutx $^{2}$, Nicole Garcia ${ }^{2}$, Hatem 6 Zaghden $^{3}$, Sami Sayadi ${ }^{3}$, Boubaker Elleuch ${ }^{1}$

7

$8{ }^{1}$ Laboratoire Eau-Energie et Environnement, ENIS, Université de Sfax, BP 1173, 3038 Sfax, 9 Tunisie

${ }^{2}$ Aix Marseille Université, CNRS/INSU, Université de Toulon, IRD, Mediterranean Institute of Oceanography (MIO) UM 110, 13288, Marseille, France

${ }^{3}$ Laboratoire des Bioprocédés Environnementaux, Centre de Biotechnologie de Sfax, Route de Sidi Mansour km 6, PO Box 1177, 3018 Sfax, Tunisie

* Corresponding author: marc.tedetti@ mio.osupytheas.fr; Phone: + 33 (0)4 860905 27;

Fax: + $33(0) 491829641$

For submission to Progress in Oceanography to the special issue MERMEX as a full research article

Revised version

29 January 2017 


\section{Abstract}

The goal of this work is to investigate the spatial distribution and sources of dissolved aliphatic and polycyclic aromatic hydrocarbons (AHs and PAHs), as well as their relationships with a series of biogeochemical parameters (total chlorophyll $a$, phaeopigment $a$, suspended particulate matter, particulate and dissolved organic carbon, and nutrients), in surface coastal waters of the Gulf of Gabès (Tunisia, Southern Mediterranean Sea). Samples were collected off the Northern and Southern coasts of Sfax city, as well as in the GabèsGhannouch area, from October-November 2014 and in March 2015. Total dissolved AH and PAH concentrations ranged from 0.02 to $6.3 \mu \mathrm{g} \mathrm{L}^{-1}$ and from 8.9 to $197.8 \mathrm{ng} \mathrm{L}^{-1}$, respectively. These data suggest that this area has been moderate-to-highly impacted by hydrocarbons compared to other Mediterranean coastal environments. The highest AH concentrations were measured off of the Sfax Northern coast (near Ezzit wadi) and in the Gabès-Ghannouch area, whereas the highest PAH concentrations were recorded in the Sfax Southern coast (near commercial and fishing harbours and the Sidi Salem channel). Analysis of the AH molecular patterns reveals that low molecular weight (LMW) compounds in these samples are dominated by $n-\mathrm{C}_{16}, n-\mathrm{C}_{17}$ and $n-\mathrm{C}_{18}$, which suggests that these samples feature high biogenic activity (in the form of bacteria or algae), and that high molecular weight (HMW) compounds display monomodal distributions centred on $n-\mathrm{C}_{25}$ and $n-\mathrm{C}_{26}$, which can be attributed to petrogenic inputs. The PAH molecular patterns are characterized by the dominance of LMW (2-3 rings) compounds and their alkylated homologues, which account for $90 \pm 7 \%$ of total PAHs. The observed PAH distribution and isomer ratios thus indicate the presence of major petrogenic contaminations. The concentrations of AHs, PAHs and dissolved organic carbon (DOC) do not correlate with each other, thus demonstrating that these three pools likely originated from different sources and subsequently underwent different processes in the Gulf of Gabès. 
Keywords: Aliphatic hydrocarbons, polycyclic aromatic hydrocarbons, Gulf of Gabès,

Mediterranean Sea, anthropogenic signatures, biogenic inputs.

\section{Introduction}

56

Hydrocarbons, including aliphatic hydrocarbons (AHs) and polycyclic aromatic hydrocarbons (PAHs), are among the most ubiquitous organic compounds in marine environments (Lipiatou and Saliot, 1991a; Roose and Brinkman, 2005; Dachs and Méjanelle, 2010). AHs, which may be defined as straight chained, branched, or cyclic non-aromatic, are herein considered to be comprise a series of resolved compounds $(R)$, including linear $n$ alkanes $\left(n-\mathrm{C}_{\mathrm{x}}\right)$ and two branched $n$-alkanes (isoprenoids), pristane (Pr) and phytane (Phy), as well as unresolved complex mixture (UCM). While AHs have several biogenic sources, including higher plant waxes, marine phyto- and zoo-plankton, bacteria and diagenetic transformations (Cripps, 1989; Rieley et al., 1991; Volkman et al., 1992; Wang et al., 1999), their anthropogenic sources mainly comprise unburned petroleum/oils (Mazurek and Simoneit, 1984; Bouloubassi and Saliot, 1993; Wang et al., 1997; Readman et al., 2002). PAHs consist of two or more fused benzene rings and are composed of parent compounds and their alkylated homologues. They are synthesized during the formation of oil (petrogenic PAHs), during the incomplete combustion of fossil fuels and biomass (pyrogenic PAHs) (Wang et al., 1999; Wurl and Obbard, 2004; Pampanin and Sydnes, 2013), and biologically produced in soils by woody plants and termites or in oceanic environments through microbial degradation of organic matter (Chen et al., 1998; Wilcke et al., 2002). Petrogenic PAHs encompass low molecular weight (LMW) 2-3 ring compounds and their alkylated homologues, whereas pyrogenic PAHs encompass high molecular weight (HMW) 
4-6 ring compounds with a low proportion of alkylated derivatives (Neff, 1979; Wang et al., 1999). PAHs, which are deleterious to living organisms (Kennish, 1992; Samanta et al., 2002), have long been recognized as high-priority contaminants by both the European Union (Official Journal of the EU 24/08/2013, Directive 2013/39/EU) and the United States Environmental Protection Agency (US EPA, 40 CFR Part 423, Appendix A to Part 423).

The Mediterranean Sea has long been considered to be one of the most polluted seas in the world (Hinrichsen, 1990; UNEP/MAP, 2012). It is believed that anthropogenic AHs and PAHs released from urban, industrial, and agricultural activities may enter Mediterranean waters through rivers (Lipiatou and Saliot, 1991b; Tolosa et al., 1996), surface runoffs, effluents (Guigue et al., 2011), atmospheric deposition (Castro-Jiménez et al., 2012) and seabased or shipping-related activities (Tsapakis et al., 2010; Tornero and Hanke, 2016). Because of their low solubility in water, AHs and PAHs are considered to be preferentially associated with particles in coastal marine waters (May et al., 1978; Gustafsson et al., 1997; Adhikari et al., 2015). Therefore, most of studies dealing with hydrocarbons in the Mediterranean Sea have focused on sediments and particles, whereas relatively little work has studied the dissolved phase of the water column (Dachs and Méjanelle, 2010; The Mermex group, 2011). However, the dissolved phase is considered as a significant compartment for hydrocarbon dynamics in the ocean. First, some studies have shown that the concentrations of hydrocarbons, mostly PAHs, in the dissolved phase are equal to or higher than those in the particulate phase of coastal and open ocean waters (Bouloubassi and Saliot, 1991; Tedetti et al., 2010; Berrojalbiz et al., 2011; Guigue et al., 2011; 2015). Second, dissolved PAHs in surface waters represent a relevant compartment to investigate the dynamics of air-water fluxes (González-Gaya et al., 2016). Third, dissolved hydrocarbons become bioconcentrated by passive diffusion and respiration and are thus more bioavailable for marine biota than are particulate hydrocarbons, for which bioaccumulation by ingestion occurs within a smaller 
variety of organisms (i.e. filter feeders) (Tilseth et al., 1984; Akkanen et al., 2012). Finally, in the dissolved phase, hydrocarbons are subjected to a variety of processes, such as volatilization (via air-water gas exchanges) (Guitart et al., 2010; González-Gaya et al., 2016), biodegradation (Jiménez et al., 2011; Sauret et al., 2016), phototransformation (Al-Lihaibi, 2003; King et al., 2014) and complexation with dissolved organic matter (DOM) (Sabbah et al., 2004; Kim and Kwon, 2010), which may in turn modify their bioavailability and thus modify their fate in marine waters (Berrojalbiz et al., 2011; Adhikari et al., 2015).

The Gulf of Gabès (Southeastern Tunisia) is one of the most productive ecosystems of the Mediterranean Sea and is the main fishing area of Tunisia (Jabeur et al., 2000; Bel Hassen et al., 2009; D'Ortenzio and Ribera d'Alcalà, 2009; The Mermex group, 2011). At the same time, the coastal zone of the Gulf of Gabès has been strongly affected by anthropogenic activity due to the recent significant expansion of the population and the intensification of industrial and agricultural activities. These anthropogenic inputs can be attributed to contributions from great urban centres (i.e., Sfax and Gabès cities), fishing and commercial harbours, several phosphoric acid production plants, municipal landfills and wastewater effluents, and industrial and agricultural waste issued from the production and storage of olive oil, chemical products, textiles, soap and paint (Aloulou et al., 2012). The Gulf of Gabès has thus recently become a site of growing interest for investigations of contaminants. Numerous studies have reported the levels of hydrocarbons in sediments (Aloulou et al., 2010; Amorri et al., 2011; Louati et al., 2001; Zaghden et al., 2005; 2007; 2014). Nonetheless, to our knowledge, no data concerning the distribution of dissolved hydrocarbons in surface waters of this ecosystem currently exist. Therefore, the overall objective of this work is to evaluate, for the first time, the origins and spatial distributions of dissolved AHs and PAHs, along with several biogeochemical parameters, in the surface waters of the Sfax and Gabès coastal areas. 


\section{Materials and Methods}

128

129

\subsection{Study area}

The Gulf of Gabès, located in the Southeastern region of Tunisia (within the Southern Mediterranean Sea), extends from the city of Chebba $\left(35^{\circ} 14^{\prime} \mathrm{N}, 11^{\circ} 09^{\prime} \mathrm{E}\right)$ to the Tunisian-

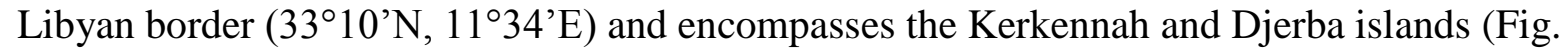

1). It is characterized by several unique geomorphologic, climatic and oceanographic conditions. First, the tidal range is one of the highest within the Mediterranean Sea, due to the width $(\sim 250 \mathrm{~km})$ and very low slope of its continental shelf (Sammari et al., 2006; Hattour et al., 2010). Second its basin is very shallow: in some areas, the water depth does not exceed a few meters over a distance of several kilometres, thus making the Gulf of Gabès very sensitive to atmospheric changes (Hattab et al., 2013) and inducing weak currents, high temperatures (14-29 ${ }^{\circ} \mathrm{C}$ ) and high salinities (38-40) in surface waters (Hamdi et al., 2015). The climate in the Gulf of Gabès is arid to semiarid (i.e., dry and sunny) with strong easterly winds (INM, 2008), resulting in severe aeolian erosion and the transportation of Saharan dusts into the sea (Jedoui, 1980; Bouaziz et al., 2003). Finally, the Gulf of Gabès is one of the most productive areas of the Mediterranean Sea [with a total chlorophyll $a$ concentration (TChl $a$ ) that can reach $20 \mu \mathrm{g} \mathrm{L}^{-1}$ ] and accounts for $65 \%$ of all Tunisian fish production (Jabeur et al., 2000; Bel Hassen et al., 2009; D’Ortenzio and Ribera d'Alcalà, 2009; DGPA, 2010; The Mermex group, 2011). Because the Gulf of Gabès is an essential region for the Tunisian economy, this coastal area has been strongly influenced by anthropogenic activity from various urban, industrial and agricultural outputs for many decades. These activities are particularly pronounced in the two largest cities of the Gulf, Sfax and Gabès (Fig. 1). 

inhabitants) and represents its economic centre. The Sfax Northern coast (which extends from

152

153 the commercial harbour to Ezzit wadi and beyond; Fig. 1) was recently restored through the Taparura project. This area features the outlet of the rainwater drain channel ("PK4"), the outlet of the Ezzit wadi, and the "Poudrière" industrial zone (Fig. 1). The Sfax Southern coast extends from the commercial harbour to the southern boundary of the Salina/Thyna agglomeration and containts the "SIAPE" phosphoric acid industry (Fig. 1). Near this industry are also the Thyna municipal landfill and the "ONAS" wastewater treatment plant (WWTP). SIAPE washing water, the WWTP effluent, and the municipal landfill leaching waters are released into the sea through a channel that joins the El Hakmouni wadi eastward of the WWTP. Moreover, the Sfax Southern coast encompasses several industrial zones, including "Madagascar", the fishing harbour and "Sidi Salem" (Fig. 1).

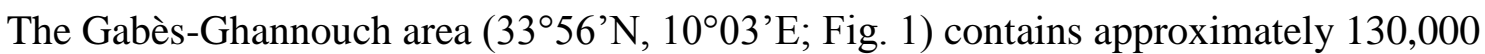
inhabitants and is characterized by important industrial and harbour activities. The "GCTGabès" phosphoric acid industry is situated along the commercial harbour. This area also houses a thermal power plant in the commercial harbour zone, petrochemical and off-shore petroleum infrastructures, and industries related to agribusiness, building materials, energy production and textiles. The El-Tine and Gabès wadis receive a variety of urban, industrial and agricultural wastes (Fig. 1) (see Text S1 for complete description of Sfax and Gabès coastal areas).

\subsection{Sampling}

Thirty-six stations were sampled in the coastal areas of Sfax (October 2014 and March 2015) and Gabès cities (November 2014) (Fig. 1; Table 1). For each transect, the most coastal station was located approximately $100 \mathrm{~m}$ (S1, S5, S8, S14, S15, S19) or $300 \mathrm{~m}$ (S12, S16, 
S22, S25, S27, S30, S33, S35) from land. With the exception of S1-S2, S5-S6, and S8-S9, which were sampled from a distance of $200 \mathrm{~m}$, all stations were located at $1000 \mathrm{~m}$ intervals along each transect (Fig. 1; Table 1). Sampling was performed on board the vessel "Taparura" between 10:30 am and 3:30 pm (18 and 23 October 2014), 8:30 am and 12:30 pm (13 November 2014), and $14 \mathrm{pm}$ and $16.30 \mathrm{pm}$ (8 March 2015). This sampling occurred around high tide and under calm sea and sunny conditions (18 and 23 October, 13 November 2014) or in cloudy weather (8 March 2015). Seawater samples were collected at a depth of $0.1 \mathrm{~m}$ using 4-L Nalgene ${ }^{\circledR}$ polycarbonate bottles (ThermoFisher Scientific, Waltham, USA), which were opened below the water surface to avoid sampling of the surface microlayer. Before their use, these bottles were extensively washed with $1 \mathrm{M}$ hydrochloric acid $(\mathrm{HCl})$ and ultrapure water (i.e., Milli-Q water from Millipore system, final resistivity: $18.2 \mathrm{M} \Omega \mathrm{cm}^{-1}$ ). They were then rinsed three times with each respective sample before being filled and placed in a cold and dark area after collection. On board, in situ measurements of temperature, salinity and $\mathrm{pH}$ were obtained using measuring cells with the TetraCon ${ }^{\circledR}$ 4-electrode system and a refractometer (WTW, Weilheim, Germany). Temperature and salinity data are not available for stations S1, S5, S8, S14, S15 and S19 (see data in Table 2).

\subsection{Filtration, handling and storage of samples}

Once in the laboratory, samples were immediately filtered under low vacuum conditions $(<50 \mathrm{~mm} \mathrm{Hg})$ through pre-combusted $\left(500{ }^{\circ} \mathrm{C}, 4 \mathrm{~h}\right) \mathrm{GF} / \mathrm{F}(\sim 0.7 \mu \mathrm{m})$ glass fibre filters $(25$ or $47 \mathrm{~mm}$ diameter, Whatman, Fisher Scientific, Illkirch, France) using glassware filtration systems. To analyse dissolved hydrocarbons (AHs and PAHs), $2 \mathrm{~L}$ of samples were filtered through 47-mm diameter GF/F filters. Filtered samples were then stored in $2.5 \mathrm{~L}$ amber glass bottles with $50 \mathrm{~mL}$ of dichloromethane $\left(\mathrm{CH}_{2} \mathrm{Cl}_{2}\right)$ at $4{ }^{\circ} \mathrm{C}$, in the dark, before undergoing solvent extraction (see §2.4). It should be noted that these filters were also used for particulate 
hydrocarbon analyses, but these results are not presented in this study. For analyses of TChl $a$ and phaeopigment $a$ (Phaeo $a$ ), 250-300 $\mathrm{mL}$ of samples were filtered through 25-mm diameter GF/F filters. Filters were stored in Nunc ${ }^{\circledR}$ cryogenic vials (Dutscher, Brumath, France) at $-20{ }^{\circ} \mathrm{C}$ until analysis. For analyses of suspended particulate matter (SPM) and particulate organic carbon (POC), between 250 and $1100 \mathrm{~mL}$ of sample, depending on their station of origin, were both filtered with pre-weighted $25-\mathrm{mm}$ diameter GF/F filters. After this filtration, filters were dried at $60{ }^{\circ} \mathrm{C}$ for $24 \mathrm{~h}$ and stored in Petrislides MilliPore ${ }^{\circledR}$ (Saint-Louis, USA) until analysis. Filtered seawater issued from this SPM and POC filtration was transferred in 100-mL Schott ${ }^{\circledR}$ glass bottles (Fisher Scientific) and in 60-mL HDPE bottles for nutrient and dissolved organic carbon (DOC) analyses, respectively. Glass and HDPE bottles were stored at $-20{ }^{\circ} \mathrm{C}$ until analysis. Nutrient, TChl $a$, Phaeo $a$, SPM, and POC analyses were not conducted for samples obtained from S1, S5, S8, S14, S15 and S19, whereas DOC analyses were not performed on samples from stations S1, S5 and S14 (see analytical procedures in $\S 2.7$ and data in Table 2).

\subsection{Hydrocarbon extraction, purification and instrumental analysis}

Dissolved hydrocarbons in the $<0.7 \mu \mathrm{m}$ size fraction were extracted from seawater using liquid-liquid extraction with $\mathrm{CH}_{2} \mathrm{Cl}_{2}(2 \times 50 \mathrm{~mL}$ per litre), according to the procedure of Guigue et al. (2011; 2014; 2015). These extracts were then concentrated by using a rotary evaporator before changing the solvent to $n$-hexane. Hexane extracts were then purified to separate the hydrocarbon fraction from more polar compounds. Extracts were fractionated within a $500 \mathrm{mg}$ silica column (Silica gel extra pure, Merck, Darmstadt, Germany), which had previously been activated at $500{ }^{\circ} \mathrm{C}$ for $4 \mathrm{~h}$ and then partially deactivated with ultrapure water $(2 \% \mathrm{w} / \mathrm{w})$. AHs and PAHs were eluted together using $2 \mathrm{~mL}$ of $n$-hexane followed by $3 \mathrm{~mL}$ of 
$n$-hexane/ $\mathrm{CH}_{2} \mathrm{Cl}_{2}(3: 1 \mathrm{v} / \mathrm{v})$ (Guigue et al., 2014; 2015). All solvents were of organic trace analysis quality (Rathburn Chemicals Ltd, Walkerburn, Scotland).

Purified hydrocarbon fractions (AHs + PAHs) were analysed by a gas chromatographmass spectrometer (GC-MS) (5977A Series GC/MSD System, Agilent Technologies, Santa Clara, USA) running at an ionization energy of $70 \mathrm{eV}$ for a $\mathrm{m} / \mathrm{z}$ range of $50-400$, and using the selected ion monitoring (SIM) mode. The GC-MS used helium at a flow rate of 1.2 $\mathrm{mL} / \mathrm{min}$ as a carrier gas and an HP-5 MS column $(30 \mathrm{~m} \times 0.25 \mathrm{~mm} \times 0.25 \mu \mathrm{m}$, J\&W Scientific, Agilent Technologies). The injector (used in splitless mode) and detector temperatures were set at 270 and $320^{\circ} \mathrm{C}$, respectively. The non-linear temperature program used for the column was as follow: $70^{\circ} \mathrm{C}$ for $3 \mathrm{~min}, 15^{\circ} \mathrm{C} / \mathrm{min}$ (ramp 1) to $150{ }^{\circ} \mathrm{C}$, and then 7 ${ }^{\circ} \mathrm{C} / \mathrm{min}$ (ramp 2) to a final temperature of $320^{\circ} \mathrm{C}$, held for $10 \mathrm{~min}$. The identification and quantification of hydrocarbons in samples and calibrations were performed in SIM mode (Guigue et al., 2014; 2015).

\subsection{Quality assurance/Quality control}

During the experiments and analyses, gloves were worn and care was taken to avoid contamination. All the glassware was washed with $1 \mathrm{M} \mathrm{HCl}$ and ultrapure water before being baked at $500{ }^{\circ} \mathrm{C}$ for $4 \mathrm{~h}$. All materials that could not be baked were washed with $1 \mathrm{M} \mathrm{HCl}$ and ultrapure water and dried at room temperature.

AH and PAH external calibration standards (04071, Fluka and 47543-U, Supelco, among others, purchased from Sigma-Aldrich) were run for peak identification, and sample quantifications were processed using internal standards. Deuterated standard mixtures, which were introduced in samples prior to extraction $\left(n-\mathrm{C}_{16}-d_{34}, n-\mathrm{C}_{24}-d_{50}, n-\mathrm{C}_{36}-d_{74}\right.$ for $\mathrm{AHs}$, and Naph- $d_{8}$, Phe- $d_{10}$, Per- $d_{12}$ for PAHs) and prior to injection (Ace- $d_{10}$, Flu- $d_{10}$ and Chrys- $d_{12}$ ), were used to determine procedural recoveries and to quantify hydrocarbons in samples. 
Average recoveries of $n-\mathrm{C}_{16^{-}} d_{34}, n-\mathrm{C}_{24}-d_{50}$ and $n-\mathrm{C}_{36^{-}} d_{74}$ were $93 \%$ for each standard, while those of Naph- $d_{8}$, Phe- $d_{10}$, Per- $d_{12}$ were 51,71 , and $84 \%$, respectively. These procedural recoveries, which include the processes of extraction, evaporation, and purification, do not take into account the potential losses of HMW dissolved hydrocarbons by sorption onto polycarbonate bottles during the few hours between the sampling and filtration steps, which are very difficult to quantify in natural samples (Delle Site, 2001). Blanks were run for the entire procedure, including extraction, solvent concentration, and purification. The total mass of all $\mathrm{AH}$ and $\mathrm{PAH}$ compounds measured in these procedural blanks represented on average 19 and $4 \%$ of the total mass of all $\mathrm{AH}$ and PAH compounds measured in these samples, respectively. For AHs, the procedural blank was mainly due to $n-\mathrm{C}_{23}, n-\mathrm{C}_{24}, n-\mathrm{C}_{30}$, and $n-\mathrm{C}_{32}$. All concentration values were blank- and recovery-corrected. Detection limits of the method used for individual compounds varied from 1 to $30 \mathrm{pg} \mathrm{L}^{-1}$ in water.

\subsection{Determination of hydrocarbon indices and ratios}

For AHs, we determined the concentration of resolved compounds $(R)$ (i.e., $n$-alkanes from $n-\mathrm{C}_{15}$ to $n-\mathrm{C}_{40}$, including Pr and Phy) and the concentration of the UCM by integrating the hump (if present) using the mean response factors of the resolved compounds. Biogenic AHs were distinguished from petrogenic AHs mainly by relying on their molecular pattern distribution and then by determining several ratios and indices. First, we used the $R / \mathrm{UCM}$ ratio as an indicator of recent petroleum contamination (when $>0.3$ ) or severe degraded petroleum contamination (when < 0.05) (Simoneit and Mazurek, 1982; Commendatore and Esteves, 2004; Asia et al., 2009; Commendatore et al., 2012). We also used the Pr/Phy ratio as an indicator of biogenic AHs (when > 1) (Cripps, 1989; Commendatore and Esteves, 2004; Cincinelli et al., 2008). However, due to the controversial origin of these isoprenoids, it is not relevant to employ this ratio as an indicator of petrogenic AHs (when it is $<1$ ). Finally, we 
used the carbon preference index $\left(\mathrm{CPI}_{15-40}\right)$, computed as the odd/even ratio in the $n$ - $\mathrm{C}_{15}-n$ $\mathrm{C}_{40}$ range, as an indicator of biogenic $\mathrm{AHs}\left(\mathrm{CPI}_{15-40}>1\right.$ or $\left.<1\right)$ or AHs issued from petroleum contaminations ( $\mathrm{CPI}_{15-40}$ 1) (Commendatore et al., 2012).

We quantified $29 \mathrm{PAH}$ compounds $\left(\sum_{29}\right.$ PAHs $\left._{-\mathrm{P}+\mathrm{A}}\right)$ in these samples. These include 19 parent PAHs (PAHs-P), which are naphthalene (Naph), acenaphthylene (Acy), acenaphthene (Ace), fluorene (Flu), dibenzothiophene (DBT), phenanthrene (Phe), anthracene (Ant), fluoranthene (Flt), pyrene (Pyr), benz[a]anthracene [BaA], chrysene (Chr), benzo[b]fluoranthene $[\mathrm{BbF}]$, benzo[k]fluoranthene $[\mathrm{BkF}]$, benzo[a]pyrene $[\mathrm{BaP}]$, benzo[e]pyrene $[\mathrm{BeP}]$, perylene (Per), dibenzo[a,h]anthracene [DA], benzo[g,h,i]perylene [BP] and indeno[1,2,3-cd]pyrene [IP]. We also quantified 10 alkylated homologues (PAHs-A), including methyl $\left(\mathrm{C}_{1}\right)$, dimethyl $\left(\mathrm{C}_{2}\right)$ and trimethyl $\left(\mathrm{C}_{3}\right)$ of Naph and Phe, and $\mathrm{C}_{1}$ and $\mathrm{C}_{2}$ of Flu and Pyr. Petrogenic and pyrogenic PAHs were discriminated mainly by relying on their molecular pattern distribution and then by determining selected ratios (Lipiatou and Saliot, 1991; Budzinski et al., 1997; Mille et al., 2007). First, we used the ratio between alkylated homologues and parent compounds (Alk/Par); generally, petrogenic PAHs are characterized by the dominance of alkylated homologues over their parent compounds (Alk/Par > 1), whereas the inverse pattern is observed for pyrogenic PAHs (Youngblood and Blumer, 1975). Second, we used the Ant/(Ant + Phe) and Flt/(Flt + Pyr) ratios, as indicators of pyrogenic (> 0.1 and $>0.5$, respectively) or petrogenic PAHs $(<0.1$ and $<0.4$, respectively) (Budzinski et al., 1997; Yunker et al., 2002; Asia et al., 2009; Li et al., 2015). It is worth noting that all these ratios and indices have to be used with precaution since hydrocarbon presence patterns may be substantially modified by many processes.

\subsection{Biogeochemical analyses}


Nutrients, such as nitrites $\left(\mathrm{NO}_{2}{ }^{-}\right)$, nitrates $\left(\mathrm{NO}_{3}{ }^{-}\right)$, phosphates $\left(\mathrm{PO}_{4}{ }^{3-}\right)$, and silicates

$299\left[\mathrm{Si}(\mathrm{OH})_{4}\right]$ were analysed using the automated colorimetric method described in Aminot and

Kérouel (2007). To obtain reproducible nutrient measurements, we used standards and compared their results to those of commercial products (OSIL Ltd, Havant, UK). The detection limits of $\mathrm{NO}_{2}{ }^{-}, \mathrm{NO}_{3}{ }^{-}$, and $\mathrm{PO}_{4}{ }^{3-}$ were $0.05,0.05$, and $0.02 \mu \mathrm{M}$, respectively.

TChl $a$ and Phaeo $a$ were analysed using the fluorescence method following a methanol extraction (Raimbault et al., 2004). Five mL of methanol (RP Prolabo, VWR France, Fontenay sous Bois, France) were added to the filter, and, after 30 minutes of extraction in the dark at $4{ }^{\circ} \mathrm{C}$, a fluorescence measurement was performed using a fluorometer from model 10 Turner Designs (Sunnyvale, USA) equipped with the Welschmeyer kit to avoid Chl $b$ interference (Welschmeyer, 1994). As the monochromatic fluorescence method cannot separate divinyl chlorophyll from chlorophyll, results are given in terms of total Chl $a$ (TChl a) concentrations, representing the sum of $\mathrm{Chl} a$ and divinyl Chl $a$. The blank "methanol + filter" was close to zero, yielding a very low detection limit of approximately $0.01 \mu \mathrm{g} \mathrm{L}^{-1}$. Calibrations were made using a pure Sigma Chl $a$ standard. We applied the acidification method to determine Phaeo $a$ concentrations (Raimbault et al., 2004).

After spending $24 \mathrm{~h}$ in the desiccator, filters were reweighed on the same balance, and the SPM concentration was calculated as the difference between the filter weight before and after sample filtration, normalised to the filtration volume (Neukermans et al., 2012). POC was then determined with an AutoAnalyser II Technicon (New York, USA) using the wetoxidation procedure established by Raimbault et al. (1999). The POC detection limit was 0.50 $\mu \mathrm{M}$.

To determine DOC, samples were acidified with orthophosphoric acid and analysed using a TOC-5000 total carbon analyser (Shimadzu, Kyoto, Japan) (Sohrin and Sempéré, 2005). Average TOC concentrations in Deep Atlantic Water and low carbon water reference 
standards were $43 \pm 2 \mu \mathrm{M} \mathrm{C}, \mathrm{n}=24$ and $1 \pm 0.3 \mu \mathrm{M} \mathrm{C}, \mathrm{n}=24$, respectively. The analytical precision of the procedure was $\leq 2 \%$.

\subsection{Statistical treatment}

Colour maps of dissolved $\mathrm{AH}$ and $\mathrm{PAH}$ concentrations were performed using Ocean Data View (ODV) software version 4.6.5 (Schlitzer, R., http://odv.awi.de, 2014.). The spatial interpolation/gridding of data was conducted using Data-Interpolating Variational Analysis (DIVA) (Barth et al., 2010; Troupin et al., 2012). Because all variables (except pH) displayed non-normal distributions and high-amplitude values (Joliffe, 1986), it was preferable to use Spearman's rank-order correlation over Pearson's correlation. Hierarchical ascendant classification (HAC) was used to find homogenous groups of individuals (stations) within the dataset, with respect to selected variables. These groups (or clusters) present a low withinvariability and are different than others (displaying high between-variability). The dissimilarity measurement between clusters was based on Ward's method, which uses squared Euclidean distance. Variable values were centred and reduced beforehand. Two different HAC were then applied: one on physical and biogeochemical parameters (i.e., T, salinity, pH, $\mathrm{NO}_{2}^{-}, \mathrm{NO}_{3}{ }^{-}, \mathrm{PO}_{4}{ }^{3-}, \mathrm{Si}(\mathrm{OH})_{4}, \mathrm{TChl} a$, Phaeo $\left.a, \mathrm{SPM}, \mathrm{POC}, \mathrm{DOC}\right)$ and the other one on selected hydrocarbon parameters (i.e., $R$, Pr/Phy, $\mathrm{CPI}_{15-40}$, for AHs, $\sum_{29}$ PAHs-P+A, Alk/Par, Flt/(Flt + Pyr) for PAHs). Clusters (groups) issued from these HAC were represented in the form of box-and-whisker plots. Principal component analysis (PCA) was also applied to these hydrocarbon variables, based on Spearman's rank-order correlation matrix. Normality tests (including Shapiro-Wilk, Jarque-Bera and Kolmogorov-Smirnov tests), Spearman's rankorder correlation matrices, HAC, and PCA were performed using XLSTAT 2013.5.01 (a Microsoft Excel add-in program), while box-and-whisker plots were completed with 
StatView 5.0. The significance threshold for these different analyses and tests was set at $\mathrm{p}<$ 0.05 .

\section{Results}

\subsection{Spatial distribution of physical and biogeochemical parameters}

Physical and biogeochemical parameters are reported in Table 2. Applying HAC to this dataset reveals the presence of six groups of stations (G1-G6; Fig. 1; Fig. 2a-i). The first group (G1) includes stations S2 and S6, which are located on the Sfax Northern coast, in front of Ezzit wadi and between Ezzit wadi and PK4 channel, respectively (Fig. 1). These stations are characterized by the highest observed POC ( 245 and $208 \mu \mathrm{M}$, respectively; Fig. $2 \mathrm{~h}$ ) and SPM concentrations (44 and $59 \mathrm{mg} \mathrm{L}^{-1}$, respectively; Fig. 2i), as well as the highest measured salinity values ( 42.0), and high TChl $a\left(16 \mu \mathrm{g} \mathrm{L}^{-1}\right.$ in S2; Fig. 2e), Phaeo $a\left(3.5 \mu \mathrm{g} \mathrm{L}^{-1}\right.$ in S6; Fig. 2f) and DOC concentrations (181 $\mu \mathrm{M}$ in S2; Fig. 2g) (Table 2). G2 includes all other stations from the Sfax Northern coast (S3, S4, S7, S9-S13) as well as station S35 from the Gabès-Ghannouch area (Fig. 1). This group is marked by the lowest observed $\mathrm{PO}_{4}{ }^{3-}(10.4 \pm$ $2.3 \mu \mathrm{M}$; Fig. 2c), TChl $a\left(3.7 \pm 1.4 \mu \mathrm{g} \mathrm{L}^{-1} ;\right.$ Fig. $\left.2 \mathrm{e}\right)$, and Phaeo $a$ concentrations $(1.3 \pm 0.6 \mu \mathrm{g}$ $\mathrm{L}^{-1}$; Fig. 2f) (Table 2). G3 encompasses stations S16 (in front of the fishing harbour), S20 (in front of the Sidi Salem channel) and S22 (in front of the El Maou wadi) on the Sfax Southern coast (Fig. 1). These stations yield the highest measured concentrations of $\mathrm{NO}_{2}^{-}(0.8 \pm 0.1$ $\mu \mathrm{M}$; Fig. 2a), $\mathrm{PO}_{4}{ }^{3-}\left(107.5 \pm 22.0 \mu \mathrm{M}\right.$; Fig. 2c), TChl $a\left(27.8 \pm 13.5 \mu \mathrm{g} \mathrm{L}^{-1}\right.$; Fig. 2e), Phaeo $a$ $\left(6.8 \pm 3.4 \mu \mathrm{g} \mathrm{L}^{-1}\right.$; Fig. 2f), and DOC (194.8 $\pm 10.7 \mu \mathrm{M}$; Fig. $\left.2 \mathrm{~g}\right)$, as well as high concentrations of $\mathrm{NO}_{3}{ }^{-}$, POC, and SPM (Fig. 2b, h, i; Table 2). Therefore, it is likely that these three stations were subjected to intense eutrophication. G4 includes the remaining stations from the Sfax Southern coast (S17, S18, S21, S23-S26) (Fig. 1), which are marked by 
the lowest concentrations of $\mathrm{Si}(\mathrm{OH})_{4}(3.1 \pm 1.4 \mu \mathrm{M}$; Fig. $2 \mathrm{~d}), \mathrm{POC}(30.7 \pm 12.8 \mu \mathrm{M}$; Fig. 2h), and SPM $\left(10.2 \pm 1.7 \mathrm{mg} \mathrm{L}^{-1}\right.$; Fig. $\left.2 \mathrm{i}\right)$, the highest $\mathrm{T}$ values $\left(26.8 \pm 0.3^{\circ} \mathrm{C}\right)$, and the lowest $\mathrm{pH}$ values $(8.0 \pm 0.05)$ (Table 2). G5 comprises stations from the Gabès-Ghannouch area (S27S32, S36) (Fig. 1), which are characterized by the lowest $\mathrm{NO}_{2}{ }^{-}$concentrations $(\sim 0 . \mu \mathrm{M}$; Fig. $2 \mathrm{a})$, the lowest salinity values $(34.7 \pm 2.4)$, and high DOC concentrations, with the highest value for S30 (217.6 $\mu \mathrm{M}$; Fig. 2g) (Table 2). Finally, G6 includes stations S33 and S34, which are located between the fishing and commercial harbours of the Gabès-Ghannouch area (Fig. 1). They record the highest concentrations of $\mathrm{Si}(\mathrm{OH})_{4}(27.6-33.4 \mu \mathrm{M}$; Fig. $2 \mathrm{~d})$ and $\mathrm{NO}_{3}{ }^{-}(3.2-$ $4.0 \mu \mathrm{M}$; Fig. 2b), as well as high concentrations of $\mathrm{PO}_{4}{ }^{3-}(35.9-42.0 \mu \mathrm{M}$; Fig. 2c) and TChl $a$ (7.7-8.7 $\mu \mathrm{g} \mathrm{L}^{-1}$; Fig. 2e) (Table 2).

\subsection{Spatial distribution of dissolved hydrocarbons}

Dissolved total AH and PAH concentrations and ratios are reported in Table 3. HAC and PCA applied to the main hydrocarbon variables from these tables reveal the presence of three groups of stations (G'1-G'3). These three groups are represented by PCA (Fig. 3) (HAC dendrogram not shown), in the form of box-and-whisker plots (Fig. 4) and colour maps (Fig. 5). AH and PAH molecular profiles are shown in Fig. 6 and Fig. 7, respectively. Stations displaying similar molecular profiles were grouped together. Below, we describe the hydrocarbon content of each of these three HAC/PCA groups.

\subsubsection{Group G'1}

Group G'1 includes the northernmost stations of Sfax (S1-S6) and all stations from the Gabès-Ghannouch region (S27-S36) (Fig. 1, 3, 5). These stations are characterized by the highest $R$ concentrations, including $\operatorname{Pr}$ and Phy, with an average of $4.7 \pm 0.7 \mu \mathrm{g} \mathrm{L}^{-1}$ (Table 3; Fig. 3, 4a, 5). UCM is present in all stations, except S3 and S6, with concentrations varying 
397

398

399

400

401

402

403

404

405

406

407

408

409

410

411

412

413

414

415

416

417

418

419

420

421

from 5.42 (S2) to $14 \mu \mathrm{g} \mathrm{L}^{-1}$ (S34), representing $63.4 \pm 5.7 \%$ of the total AH pool (Table 3).

When present, $R / \mathrm{UCM}$ values are all $>0.30$ (Table 3 ). This group exhibits the lowest $\mathrm{Pr} / \mathrm{Phy}$ ratios, which vary from 0.27 (S3) to 0.36 (S30, S33) (Table 3; Fig. 4b). AH molecular profiles display monomodal distributions centred on $n-\mathrm{C}_{25}-n-\mathrm{C}_{26}$ compounds (Fig. 6a). An equal amount of even and odd carbon numbered $n$-alkanes is also observed, resulting in $\mathrm{CPI}_{15-40}$ values close to 1 (Table 3; Fig. 4c).

Concentration of $\sum_{29}$ PAHs $_{-\mathrm{P}+\mathrm{A}}$ was $29.7 \pm 12.1 \mathrm{ng} \mathrm{L}^{-1}$ (Table 3; Fig. 3, 4d, 5). Alk/Par ratios range from 0.6 (S3) to 5.5 (S33) but are mainly > 2 (Table 3; Fig. 4e). PAHs $-\mathrm{P}+\mathrm{A}$ pattern distributions are marked by the dominance of LMW compounds (2-3 rings) over HMW compounds ( $\geq 4$ rings) (Fig. 7a, f), the former representing $88 \pm 4 \%$ of total PAHs.

Naphthalenes $\left(\mathrm{C}_{2}\right.$-Naph $>\mathrm{Naph}>\mathrm{C}_{3}$-Naph $>\mathrm{C}_{1}$-Naph $)$ represent the major compounds, followed by phenanthrenes $\left(\mathrm{C}_{1}-\mathrm{Phe}>\mathrm{C}_{2}\right.$-Phe $>$ Phe $>\mathrm{C}_{3}$-Phe $)$. Nevertheless, the heavy compounds $\mathrm{C}_{1}$-Pyr and Pyr are also present in significant proportions in these stations $(6.4 \pm$ 4.8 and $3.8 \pm 3.9 \%$, respectively) (Fig. $7 \mathrm{a}, \mathrm{f}$ ). The Flt/(Flt + Pyr) ratios range from 0.08 to 0.38 (Table 3; Fig. 4f).

\subsubsection{Group $G^{\prime} 2$}

Group G'2 contains the southernmost stations of the Sfax North coast (S7-S13) as well as most stations from the Sfax Southern coast (S16-S18, S20-S26) (Fig. 1, 3, 5). These stations are distinguished by the lowest $R$ concentrations $\left(0.13 \pm 0.25 \mu \mathrm{g} \mathrm{L}^{-1}\right)$ and the absence of UCM (Table 3; Fig. 3, 4a, 5). Pr/Phy ratios vary from 0.51 (S7) to 2.43 (S21) but are mainly > 1 (Table 3; Fig. 4b). AH molecular profiles also vary within this group. S7 and S11 reveal distributions similar to those of G'1 stations (i.e., monomodal distribution centred on the $n-\mathrm{C}_{25}-n-\mathrm{C}_{26}$ range) (Fig. 6a) and do not display any odd-to-even carbon-numbered dominance $\left(\mathrm{CPI}_{15-40} \sim 1\right)$ (Fig. 3, 4c). The molecular profiles of S8 and $\mathrm{S} 17$ are marked by a 
regular distribution of $n$-alkanes in the $n-\mathrm{C}_{15}-n-\mathrm{C}_{38}$ range, with the maximal abundance of $n$ $\mathrm{C}_{29}$ (Fig. 6c) resulting in a slight odd-to-even carbon-numbered predominance $\left(\mathrm{CPI}_{15-40}=1.3\right.$ and $\sim$, respectively) (Fig. 3, 4c). A bimodal distribution of $n$-alkanes is observed at S26 and $\mathrm{S} 13$, in which light compounds are centred on $n-\mathrm{C}_{16}(\mathrm{~S} 26)$ or $n-\mathrm{C}_{15}(\mathrm{~S} 13)$ and heavy compounds are centred on $n-\mathrm{C}_{28}(\mathrm{~S} 26)$ or $n-\mathrm{C}_{33}(\mathrm{~S} 13)$ (Fig. 6d,e). In contrast, the molecular profiles of stations S9, S10, S12, S16, S18 and S20-S25 also display monomodal distributions but feature a strong even-to-odd predominance within the $n-\mathrm{C}_{16}-n-\mathrm{C}_{22}$ range (Fig. 6f). This trend results in low $\mathrm{CPI}_{15-40}$ values (0.11-0.89), with $n$ - $\mathrm{C}_{16}$ being the major compound, followed by $n-\mathrm{C}_{18}$ (Table 3; Fig. 3, 4c). Globally, $\mathrm{CPI}_{15-40}$ values for this group are $<1$ (Table 3, Fig. 4c).

G'2 stations record PAH concentrations similar to those of G'1 stations, with $\sum_{29}$ PAHs. ${ }_{\mathrm{P}+\mathrm{A}}$ of $28.9 \pm 16.2 \mathrm{ng} \mathrm{L}^{-1}$ (Table 3; Fig. 3, 4d, 5). Alk/Par ratios are lowest in G'2, ranging from 0.25 to 2.25 (but mainly falling between 1 and 2) (Table 3; Fig. 3, 4e). PAH molecular profiles reveal the predominance of LMW compounds (Fig. 7a-e), as LMW compounds represent $89.2 \pm 8.2 \%$ of all total PAHs. Naphthalenes are the dominant compounds, followed by phenanthrenes (Fig. 7a-e). Heavy compounds are also present in these stations, with $\mathrm{C}_{1^{-}}$ Pyr and Pyr in S7, Flt in S8, Flt and Chr in S21-S26 (Fig. 7a, b, e). Flt/(Flt + Pyr) ratios are the highest in this group, with values exceeding 0.5, except at S7 and S11 (Table 3; Fig. 3, 4f).

\subsubsection{Group G'3}

Group G'3 comprises only three stations from the Sfax Southern coast: S14, S15 and $\mathrm{S} 19$ (Fig. 1, 3, 5). $R$ concentration is high in $\mathrm{S} 14\left(4.5 \mu \mathrm{g} \mathrm{L}^{-1}\right)$ and low in $\mathrm{S} 15$ and $\mathrm{S} 19(0.04$ and $0.03 \mu \mathrm{g} \mathrm{L}^{-1}$, respectively) (Table 3; Fig. 3, 4a, 5). S14 displays a molecular distribution similar to those of G'1 stations (i.e., monomodal distribution centred on the $n-\mathrm{C}_{25}-n-\mathrm{C}_{26}$ 
range), with UCM present at a concentration of $7.4 \mu \mathrm{g} \mathrm{L}^{-1}$, representing $62.2 \%$ of total AHs (Table 3; Fig. 6a). Stations S15 and S19 exhibit different molecular profiles, with an almost regular distribution from $n-\mathrm{C}_{15}$ to $n-\mathrm{C}_{36}$ and the slight emergence of $n-\mathrm{C}_{17}$ and Phy (Table 3; Fig. 3, 6b). Within these three stations, Pr/Phy are low (0.34-0.48) and equal amounts of even- and odd-carbon-numbered $n$-alkanes can be found (CPI 1) (Table 3; Fig. 4b, c). These stations contain the highest recorded PAH concentrations, with $175.8 \pm 20.7 \mathrm{ng}$ $\mathrm{L}^{-1}$ (Table 3; Fig. 3, 4d, 5). Molecular profile of the PAHs reveals the predominance of LMW compounds (Fig. 7d), as inferred by the presence of the highest Alk/Par ratios $(6.6 \pm 0.6)$ (Table 3; Fig. 3, 4e). The LMW compounds represent $97.6 \pm 0.3 \%$ of all total PAHs. Naphthalenes are the dominant compounds, followed by phenanthrenes and fluorenes, whereas the HMW compounds are almost undetectable (Fig. 7d). The Flt/(Flt + Pyr) ratios are among the lowest measured values (0.08-0.13; Table 3; Fig. 3, 4f).

Additionally, we can also use the cross plot of Ant/(Ant + Phe) versus Flt/(Flt + Pyr) ratios to distinguish different origins of PAHs (Yunker et al., 2002, 2015), as shown in Fig. 8. Most stations reveal mixed origins of PAHs. All stations in G'3 and G'1 yield Ant/(Ant + Phe) $>0.1$ and Flt/(Flt + Pyr) $<0.4$ (mixed origin), except S2, S3, S4, S6, which are strictly of petrogenic origin. In contrast, G'2 stations record Ant/(Ant + Phe $)<0.1$ and Flt/(Flt + Pyr $)>$ 0.5 (mixed origin), except S8, which has a pyrogenic origin, and S7 and S11, which are strictly of petrogenic origin. Therefore, the clustering of the highly contaminated G' $1+G^{\prime} 3$ stations in an area where Flt/(Flt + Pyr $)<0.4$ along with the clustering of the less contaminated G'2 group (displaying more degraded hydrocarbons) in an area where Ant/Ant+Phe $<0.1$, very likely suggests that PAHs have different origins in G' $1+G^{\prime} 3$ than they do in G'2.

\subsection{Correlation between biogeochemical parameters and dissolved hydrocarbons}


Table 4 displays the Spearman's rank-order correlation matrix for biogeochemical parameters and dissolved hydrocarbons. $R$ concentration is significantly negatively correlated with $\mathrm{T}(\mathrm{r}=-0.68, \mathrm{n}=30, \mathrm{p}<0.05)$ and significantly positively correlated with $\mathrm{Si}(\mathrm{OH})_{4}$ concentration $(\mathrm{r}=0.56, \mathrm{n}=30, \mathrm{p}<0.05)$. The concentration of $\sum_{29}$ PAHs $_{-\mathrm{P}+\mathrm{A}}$ shows a significant negative correlation with $\mathrm{pH}(\mathrm{r}=-0.47, \mathrm{n}=30, \mathrm{p}<0.05)$ and significant positive correlation with concentrations of $\mathrm{NO}_{3}{ }^{-}, \mathrm{PO}_{4}{ }^{3-}, \mathrm{Si}(\mathrm{OH})_{4}$ and TChl $a(\mathrm{r}=0.39-0.66, \mathrm{n}=30, \mathrm{p}<$ 0.05). Neither $R$ concentrations nor $\sum_{29} \mathrm{PAHs}_{-\mathrm{P}+\mathrm{A}}$ concentrations are correlated to DOC concentrations $(r=0.01-0.20, n=30, p>0.05)$. No significant relationship was found between $R$ and $\sum_{29}$ PAHs $_{-\mathrm{P}+\mathrm{A}}$ concentrations $(\mathrm{r}=-0.07, \mathrm{n}=36, \mathrm{p}>0.05)$, suggesting that AHs and PAHs in this coastal area are decoupled. Evidence for this decoupling can also be seen in results of the PCA, in which $\mathrm{AH}$ and PAH variables are located on principal component 1 (PC1) and principal component 2 (PC2), respectively, thus underscoring their absence or very low correlation (Fig. 3). TChl $a$ concentrations are significantly positively correlated to those of $\mathrm{NO}_{3}{ }^{-}, \mathrm{PO}_{4}{ }^{3-}, \mathrm{Si}(\mathrm{OH})_{4}$, Phae $a, \mathrm{SPM}, \mathrm{POC}$ and DOC $(\mathrm{r}=0.40-0.70, \mathrm{n}=30, \mathrm{p}<0.05)$. This underlines the strong coupling between phytoplankton biomass, nutrients and the organic carbon pool (Table 4). The absence of any correlation between POC and DOC concentrations, as well as the positive correlation observed between DOC and SPM concentrations, suggest the presence of slightly different sources of particulate and dissolved organic carbon in the surface waters.

\section{Discussion}

\subsection{Comparisons with previously published data}




\subsubsection{Physical and biogeochemical parameters}

Measured temperature and $\mathrm{pH}$ values in this study, which range from $18.0-27.3{ }^{\circ} \mathrm{C}$ and 7.90-8.30, respectively (Table 2), are within the same order of magnitude as those reported in other studies in the Gulf of Gabès (Drira et al., 2014; 2016; Rekik et al., 2014) and in the Western Mediterranean basin (Pujo-Pay et al., 2011). Salinity, however, displays a wider range (32-42) than has been observed by previous works in this coastal area (i.e., 36-40 by Drira et al., 2016). This is likely because stations in this study are located closer to the coast and are thus more influenced by terrestrial freshwater inputs for the lower values and by a thinner water column subjected to greater evaporation for the higher ones.

$\mathrm{NO}_{2}{ }^{-}$concentrations measured here $(0.00-0.90 \mu \mathrm{M}$; Table 2$)$ are similar to those already reported in these coastal waters $(0.01-0.83 \mu \mathrm{M})$, whereas $\mathrm{NO}_{3}{ }^{-}$and $\mathrm{Si}(\mathrm{OH})_{4}$ concentrations (0.01-4.0 and 1.4-33.4 $\mu \mathrm{M}$, respectively; Table 2) are lower than previously reported values (1.2-13.4 and 2.6-55.2 $\mu \mathrm{M}$, respectively) (Rekik et al., 2013; Drira et al., 2016). $\mathrm{PO}_{4}{ }^{3-}$ concentrations measured here (5.5-120.3 $\mu \mathrm{M}$; Table 2) are higher than those that have previously been recorded in this area (0.1-39.7 $\mu \mathrm{M})$ (Rekik et al., 2012, 2013; Drira et al., 2016). The highest $\mathrm{PO}_{4}{ }^{3-}$ concentrations are found in the Sfax Southern coast (G3 group: stations S16, S20, S22; Fig. 1, 2c; Table 2) and can be attributed, in part, to the release of phosphogypsum from the SIAPE industry, which is known to be enriched in $\mathrm{PO}_{4}{ }^{3-}$, as well as to the release of domestic and industrial wastes from the Sidi Salem channel. The lowest $\mathrm{PO}_{4}{ }^{3-}$ concentrations are observed mainly in the Sfax Northern coast (G2 group; Fig. 1, 2c;

Table 2), where phosphoric acid activities have not occurred for several years.

TChl $a$ concentrations measured in the present work (1.7-40.7 $\mu \mathrm{g} \mathrm{L}^{-1}$; Table 2) are higher than those previously found in the same coastal waters $\left(0.0-25.6 \mu \mathrm{g} \mathrm{L}^{-1}\right.$ ) (Rekik et al., 2013; 2014), while our SPM concentrations (8.3-59.4 $\mathrm{mg} \mathrm{L}^{-1}$; Table 2) are on the same order 
521 of magnitude (0.7-30 $\left.\mathrm{mg} \mathrm{L}^{-1}\right)$ (Katlane et al., 2013) and lower than those measured in the

522 Northern coast of Sfax (14-434 $\left.\mathrm{mg} \mathrm{L}^{-1}\right)$ (Rekik et al., 2014).

523

524

525

526

527

528

529

530

531

532

533

534

535

536

537

538

539

540

541

542

543

544

545

Therefore, these data suggest that this coastal area is characterized by an enrichment in $\mathrm{PO}_{4}{ }^{3-}$, TChl $a$, POC, DOC and SPM concentrations compared to other Mediterranean systems (The Mermex group; Pujo-Pay et al., 2011; Karydis and Kitsiou, 2012). $\mathrm{PO}_{4}{ }^{3-}$ anthropogenic inputs from various industrial sources have led to the eutrophication (or the enhancement of biological production) of these coastal waters (Ben Mustapha et al., 1999; Drira et al., 2014; 2016). The high variability in concentrations from station to station may be related not only to different anthropogenic input contributions, but also to the complex bathymetry and hydrodynamics of this area.

\subsubsection{Dissolved n-alkane and PAH concentrations}

Compared to PAHs, only a few studies have investigated dissolved $n$-alkanes in marine waters. Dissolved total $R$ concentrations ( $n-\mathrm{C}_{15}-n-\mathrm{C}_{40}$ with $\mathrm{Pr}$ and Phy) determined here in the surface waters of the Sfax and Gabès coastal areas (0.02 to $6.3 \mu \mathrm{g} \mathrm{L}^{-1}$; Table 3$)$ yield higher values than those recorded in surface waters of the Marseille coastal area (Northwestern Mediterranean Sea, France) $\left(0.04-0.58 \mu \mathrm{g} \mathrm{L}^{-1}\right)$ (Guigue et al., 2011; 2014), in offshore surface waters of the Northwestern Mediterranean Sea (0.7-2.4 $\left.\mu \mathrm{g} \mathrm{L}^{-1}\right)$ (Marty and Saliot, 1976) and in surface waters of the Gulf of Tunis (Tunisia) (0.25-1 $\mu \mathrm{g} \mathrm{L}^{-1}$; Mzoughi and Chouba, 2011). Dissolved total PAH concentrations measured here in the surface waters of the Sfax and Gabès coastal areas, i.e., $8.9-197.8 \mathrm{ng} \mathrm{L}^{-1}$ for $\sum_{29} \mathrm{PAHs}_{-\mathrm{P}+\mathrm{A}}$ and 3.6-56.4 $\mathrm{ng} \mathrm{L}^{-1}$ for $\sum_{19}$ PAHs. P, are high compared to those reported in the Western Mediterranean ( $\sum_{16}$ PAHs $_{-\mathrm{P}+\mathrm{A}}$ : $0.4-2.2$ ng L ${ }^{-1}$ and $\sum_{19}$ PAHs-P+A $_{-}$0.16-0.8 $\left.\mathrm{ng} \mathrm{L}^{-1}\right)$ and the Eastern Mediterranean $\left(\sum_{19}\right.$ PAHs-P+A: $_{-}$:

0.16-8.8 $\mathrm{ng} \mathrm{L}^{-1}$ ) (Dachs et al., 1997; Berrojalbiz et al., 2011), as well as in coastal waters of Barcelona (Spain) and Banyuls-sur-Mer (France) $\left(\sum_{15} \mathrm{PAHs}_{-\mathrm{P}+\mathrm{A}}: 2.5-41.7 \mathrm{ng} \mathrm{L}^{-1}\right.$ in surface 
micro layer and 3.6-30.7 $\mathrm{ng} \mathrm{L}^{-1}$ in surface waters) (Guitart et al., 2007). However, they are within the same range as those observed in surface waters of the Marseille coastal area $\left(\sum_{32}\right.$

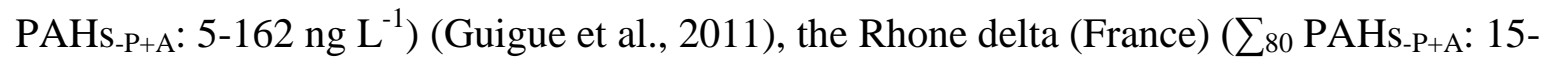
$290 \mathrm{ng} \mathrm{L}^{-1}$ ) (Bouloubassi and Saliot, 1991), and the Venice Lagoon (Italy) ( $\sum_{20}$ PAHs$_{-\mathrm{P}+\mathrm{A}}$ : 12.4-266.8 $\mathrm{ng} \mathrm{L}^{-1}$ ) (Manodori et al., 2006). Our measured concentrations are also lower than those found in the Gulf of Tunis ( $\sum_{24}$ PAHs $_{-\mathrm{P}+\mathrm{A}}$ : $139-694 \mathrm{ng} \mathrm{L}^{-1}$ in summer and $150-1008 \mathrm{ng}$ $\mathrm{L}^{-1}$ in winter) (Mzoughi and Chouba, 2011) and the Saronikos Gulf (Greece) $\left(\sum_{17} \mathrm{PAHs}_{-\mathrm{P}+\mathrm{A}}\right.$ : 103-459 $\mathrm{ng} \mathrm{L}^{-1}$ ) (Valavanidis et al., 2008). El Nemr and Abd-Allah (2003) also reported higher concentrations of PAHs $_{-}$in surface waters of the Alexandria coast (Egypt) $\left(\sum_{7} \mathrm{PAHs}_{\text {. }}\right.$ p: 13-120 ng L $\mathrm{L}^{-1}$ ). Consequently, these $\mathrm{AH}$ and $\mathrm{PAH}$ concentration data indicate that the surface coastal waters of the Gulf of Gabès are likely moderately-to-highly contaminated when compared to other Mediterranean regions. Hence concentration levels of hydrocarbons recorded in surface waters of the Gulf of Gabès are not so high compared to other Mediterranean coastal environment despite strong anthropogenic releases. This could be explained by the influence of hydrodynamic conditions, in particular tides. Tides of the Gulf of Gabès, which present the highest amplitude of all the Mediterranean Sea, with the upper Adriatic, may have a role of dispersing hydrocarbons at sea.

\subsection{Origin and potential sources of dissolved hydrocarbons}

\subsubsection{Group G'1}

$\mathrm{AH}$ and $\mathrm{PAH}$ concentrations and ratios $(R / \mathrm{UCM}>0.3 ; \mathrm{CPI} \sim 1$ and $\mathrm{Alk} / \mathrm{Par}>2)$ indicate the presence of recent and chronic petrogenic contaminations (Simoneit and Mazurek, 1982; Wang et al., 1999; Commendatore and Esteves, 2004; Commendatore et al., 2012). Additionally, the cross plot and occurrence of Pyr and $C_{1}$-Pyr suggest, for many of 
571

572

these stations, a contribution of pyrogenic (combustion) sources (Fig. 7, 8). AH profiles display a molecular distribution very close to that recorded for classic heavy fuels or residuals used as marine diesel and for industrial power generation (Wang and Fingas, 2003). This observed high proportion of alkylated homologues was also reported in Sfax surficial sediments by Zaghden et al. (2014). The hydrocarbon contamination found in the northernmost stations of Sfax and in the Gabès-Ghannouch stations may have several sources, especially wadis, uncontrolled discharges, and harbour activities. The Ezzit wadi, which may transport various uncontrolled domestic, industrial, and agricultural wastes, would thus represent a significant source of petrogenic hydrocarbons for the Northern coast of Sfax.

Within the Gabès coastal area, the main sources of hydrocarbons include industrial discharges (from the thermal power plant), commercial and fishing harbours (by means of oil spills, ballast water, shipping, and air emissions) and wadis (El-Tine and Gabès wadis) (Fig. 1). Despite the weak correlation between biogeochemical and hydrocarbon individual parameters, this observed G'1 station contamination is supported by the presence of widespread anthropisation occurring in the northernmost Sfax stations (G1) and in the GabèsGhannouch area (G5 + G6 stations).

\subsubsection{Group G'2}

This group is characterized by a range of diverse $\mathrm{AH}$ profiles, from the most petrogenic distribution (S7, S11, close to G'1 profiles; Fig. 3, 6a) to increasingly biogenic origin markers (away from G'1 profiles, Fig. 3, 6c-f). The emergence of odd $n$-alkanes $n$ - $\mathrm{C}_{15}, n-\mathrm{C}_{17}, n-\mathrm{C}_{29}, n$ $\mathrm{C}_{33}$ may be attributed to phytoplankton or higher plant debris lysis (Douglas and Eglington, 1966; Blumer et al., 1971; Goutx and Saliot, 1980), as well as the suspected presence of small-size phytoplankton cells (picophytoplankton). Since micro and macro algae are abundant in the Gulf of Gabès (Bel Hassen et al., 2008; Drira et al., 2014; Rekik et al., 2014), 
this assumption seems plausible. Even $n$-alkanes can be attributed to microbial activities such as bacteria, fungi and yeast (Elias et al., 1997). Stations S9, S10, S12, S16, S18, S20-25, which yield the lower CPI, exhibit higher abundances of these microbial signatures (Fig. 3, 6f). The hypothesised biogenic signatures of AHs within this group are supported by the presence of $\mathrm{Pr} / \mathrm{Phy}$ ratios $>1$ (Fig. 4b, c). Also, the relatively low concentration levels of AHs and PAHs, associated with low Alk/Par values (compared to the two other groups), suggest at these sites less petrogenic inputs, and, at the same time, more pronounced weathering processes, very likely through biodegradation. Indeed, it has been shown that the bacterial degradation of PAHs could lead to a depletion of alkylated PAHs compared to their non alkylated counterparts (Vila et al., 2010; Jiménez et al., 2011).

\subsubsection{Group G'3}

This group is mainly characterized by the highest PAH concentrations, LMW PAH abundances, and Alk/Par values associated with CPI 1, which indicate the importance of local petrogenic inputs. These stations were sampled in March 2015 close to the coast and were thus likely affected by anthropogenic inputs from Sidi Salem channel as well as by fishing and commercial harbours located in the Southern coast of Sfax. The Sidi Salem channel contains, among other things, untreated wastewater from slaughter-house, whose flow rate is estimated at $55 \mathrm{~m}^{3}$ day $^{-1}$, sludge from the WWTP, and pretreated wastewaters of various industries (DGQEV, 2008). Therefore, all these inputs may substantially contribute to the PAH content in this area.

\subsubsection{Differences between Sfax and Gabès environments}

In the Sfax region, we observe a combination of petrogenic inputs (G'1, G'3) and biogenic sources (G'2), as well as the occurrence of weathering processes which are 
supported by the decrease in both $\mathrm{AH}$ and $\mathrm{PAH}$ concentrations and Alk/Par ratio off of the coast (G'2: S1-S3/S4, S5-S7, S8-S11, S12-S13, S16-S18, S19-S26). Even though these weathering processes seem to be driven by biodegradation (Vila et al., 2010; Jiménez et al., 2011), we cannot exclude other processes such as volatilisation (Jiménez et al., 2012), photodegradation (King et al., 2014) and particle sequestration (Dachs et al., 2002). These biogenic AHs and weathering processes are not observed in the Gabès-Ghannouch region; we assume that this is due to either the recurrence of larger releases in Gabès, with continuous and direct discharge of phosphogypsum into the sea, or to a particular ecosystem in Sfax that is more suitable for the biodegradation of hydrocarbons. Measurements of bacterial abundance, diversity and activities in these two ecosystems should thus be considered as complements to hydrocarbon analysis in future studies. Moreover, in the Sfax waters, we did not observe coupling between the hydrocarbon and biogeochemical contents, whereas hydrocarbons in the Gabès-Ghannouch area (G'1 stations) are associated with biogeochemical groups G5 and G6, which exhibit the highest measured values of silica. These data may thus reflect the influence of terrigenous inputs (Gabès and El-Tine wadis), chronic releases or spills/plumes (harbour activities, phosphogypsum releases).

\subsubsection{Inputs of PAHs from particles}

For each of the three hydrocarbon groups, the cross plot shows the superposition of pyrogenic inputs in addition to the widespread existence of petrogenic sources (Fig. 8). This pyrogenic component probably reflects the influence of either high suspended matter contents or of the proximity of sediment. Given the dynamics of the area, we may assume that we are not in a particle-dissolved equilibrium position and thus that rearrangements may occur in cases of environmental disturbance (Dong et al., 2015). Dissolved PAHs found here in surface waters may partially originate from surficial sediments. Indeed, in these very shallow waters, 
exchanges between sediment and the water column are exacerbated. Studies carried out on surficial sediments of the Sfax coastal area have demonstrated that phenanthrenes (especially alkylated homologues) are among the most abundant PAHs (Zaghden et al., 2007; 2014).

Consequently, some LMW PAHs recorded in surface waters may be released from sediments, either by the resuspension of particulate matter or by passive diffusion. This process of partitioning between the two matrixes (water and sediment) is highly related to the octanol/water partition coefficients $\left(\mathrm{K}_{\mathrm{ow}}\right)$ of PAHs, as well as to the organic carbon content in sediment that controls this partitioning through a linear free energy relationship (Zhou and Maskaoui, 2003).

\subsection{PAH partitioning in the dissolved phase}

DOC is considered as one of the most important factors controlling the partitioning of hydrocarbons in the dissolved phase. Although we record high DOC concentrations in these coastal waters, no linear correlation is found between DOC and dissolved $\sum_{29} \mathrm{PAHs}_{-\mathrm{P}+\mathrm{A}}$ concentrations $(r=0.01, n=30, p>0.05)$. In addition, no linear correlation is observed between individual PAH and DOC concentrations, except for Ace (data not shown). This lack of correlation between DOC and dissolved PAHs may a reflect different sources for these two pools in surface waters of the Gulf of Gabès, but also their low affinity at the molecular level. Therefore, a fraction of dissolved LMW PAHs in this area could be under freely form (i.e., not complexed to dissolved organic matter), which is in agreement with their physicochemical properties (relatively low $\mathrm{K}_{\mathrm{ow}}$ and high solubility) (Shi et al., 2007). Besides, significant negative linear relationships are found between individual PAH concentrations and their respective $\mathrm{K}_{\mathrm{ow}}$ values (data not shown), which suggests that the molecular distribution pattern observed, i.e., dominance of LMW PAHs in all samples, is driven by the hydrophobic character of compounds. Interestingly, significant positive correlations are detected between 
671

672

673

674

675

several dissolved PAHs ( $\mathrm{C}_{2}$-Naph, $\mathrm{C}_{3}$-Naph, Ace, Flu, $\mathrm{C}_{1}$-Flu, $\mathrm{C}_{2}$-Flu and DBT) and POC or SPM concentrations (data not shown). This could underline a "particle concentration effect" (Zhou et al., 1999). The latter is observed when particle partition coefficient $\left(K_{p}\right.$ or $\left.K_{o c}\right)$ is inversely proportional to particle concentration. The increase in particle concentration is generally associated to an increase in DOC concentration, which may explain this distribution of PAHs towards the dissolved phase (Zhou et al., 1999). However, in our case, the increase in POC/SPM concentrations was not concomitant to an increase in DOC concentrations. Our results thus illustrate the complexity of the relationships between dissolved PAHs, DOC and POC in marine coastal waters.

\section{Conclusions}

While some works have already reported hydrocarbon levels in surficial sediments of the Sfax coastal area (Zaghden et al., 2007; 2014), this present study represents to our knowledge the first assessment of concentrations of dissolved hydrocarbons (28 AHs and 29 PAHs) in surface waters of the Gulf of Gabès (in the Sfax and Gabès coastal areas), and their associations with biogeochemical parameters. Overall, these areas are moderate-to-highly impacted by hydrocarbons and show a relatively high eutrophication level compared to other Mediterranean coastal environments. The highest hydrocarbon concentrations can be attributed to recent petrogenic sources from industrial, domestic and harbour activities. Interestingly, biogenic AHs and signatures of weathering processes are found in Sfax, but not in Gabès, with lower hydrocarbon contents and decreasing Alk/Par ratios off the coast.

Concentrations in AHs, PAHs, and DOC do not correlated with each other, thus highlighting that these three pools have different sources and are then submitted to different processes in the Gulf of Gabès. Despite these relatively high DOC concentrations, dissolved PAHs do not 
seem to show an affinity towards dissolved organic matter. These results demonstrate that the dissolved phase can provide very interesting information about the dynamics of PAHs in coastal waters. Further investigations should take into consideration the particulate organic matter of water column to obtain a global view of PAH dynamics in coastal waters of the Gulf of Gabès.

Acknowledgements. We are grateful to the "Institut de Recherche pour le Développement" (IRD) for providing scholarship to R. Fourati through the "Allocations de Rercherche pour une Thèse au Sud" (ARTS) program. This thesis was also supported by the Tunisian Ministry of Higher Education and Scientific Research. This work was conducted in the framework of the IRD Action South project "MANGA" and the IRD French-Tunisian International Joint Laboratory (LMI) "COSYS-Med". This study was carried out as a part of the WP3 C3A-Action MERMEX/MISTRALS and is a contribution to the international SOLAS, IMBER and LOICZ projects. We warmly thank Z. Drira from the laboratory of Biodiversity and Aquatic Ecosystems (Faculty of Sciences, University of Sfax) as well as H. Sahnoun and T. Omar for their technical help during cruises. We thank the core parameter analytical platform (PAPB) of the Mediterranean Institute of Oceanography (MIO) for performing biogeochemical analyses as well as R. Sempéré for the use of the Agilent GC-MS. We acknowledge two anonymous reviewers for their relevant comments and corrections.

(1) 


\section{References}

722 Adhikari, P.L., Maiti, K., Overton, E., 2015. Vertical fluxes of polycyclic aromatic hydrocarbons in the northern Gulf of Mexico. Mar. Chem., 168, 60-68.

724

Akkanen, J., Tuikka, A., Kukkonen, J.V.K., 2012. On the borderline of dissolved and particulate organic matter: Partitioning and bioavailability of polycyclic aromatic hydrocarbons. Ecotoxicol. Environ. Saf. 78, 91-98.

Al-Lihaibi, S.S., 2003. Photo-oxidation products of petroleum hydrocarbons in the Eastern Red Sea coastal waters. Environ. Inter. 28, 573-579.

Aloulou, F., Elleuch, B., Kallel, M., 2012. Benthic foraminiferal assemblages as pollution proxies in the northern coast of Gabes Gulf, Tunisia. Environ. Monit. Assess. 184, 777-95.

Aloulou, F., Kallel, M., Dammak, M., Elleuch, B., Saliot, A., 2010. Even-numbered nalkanes/n-alkenes predominance in surface sediments of Gabes Gulf in Tunisia. Environ. Earth Sci. 61, 1-10.

Aminot A., Kérouel R., 2007. Dosage automatique des nutriments dans les eaux marines : méthodesen flux continu. Ed. Ifremer, Méthodes d'analyse en milieu marin 188p.

Amorri, J., Geffroy-Rodier, C., Boufahja, F., Mahmoudi, E., Aïssa, P., Ksibi, M., Amblès, A., 2011. Organic matter compounds as source indicators and tracers for marine pollution in a western Mediterranean coastal zone. Environ. Sci. Pollut. Res. 18, 1606-1616.

Asia, L., Mazouz, S., Guiliano, M., Doumenq, P., Mille, G., 2009. Occurrence and distribution of hydrocarbons in surface sediments from Marseille Bay (France). Mar. Pollut. Bull. 58, 443-451.

Barth, A., Alvera Azcarate, A., Troupin, C., Ouberdous, M., Beckers, J.-M., 2010. A web interface for griding arbitrarily distributed in situ data based on Data-Interpolating Variational Analysis (DIVA). Adv. Geosci. 28, 29-37.

Bel Hassen, M., Drira, Z., Hamza, a., Ayadi, H., Akrout, F., Issaoui, H., 2008. Summer 
phytoplankton pigments and community composition related to water mass properties in the Gulf of Gabes. Estuar. Coast. Shelf Sci. 77, 645-656.

748

749

750

751

752

753

754

755

756

757

758

759

760

761

762

763

764

765

766

767

768

Bel Hassen, M., Drira, Z., Hamza, a., Ayadi, H., Akrout, F., Messaoudi, S., Issaoui, H., Aleya, L., Bouaïn, A., 2009. Phytoplankton dynamics related to water mass properties in the Gulf of Gabes: Ecological implications. J. Mar. Syst. 75, 216-226.

Ben Mustapha, K., Hattour, A., Mhetli, M., El Abed, A., Tritar. B., 1999. Bionomie des étages infra et circalittoral du golfe de Gabès. Bull. Inst. Natl. Sci. Tech. Mer (Tunisie) 26, $5-48$.

Berrojalbiz, N., Dachs, J., Ojeda, M.J., Valle, M.C., Castro-Jiménez, J., Wollgast, J., Ghiani, M., Hanke, G., Zaldivar, J.M., 2011. Biogeochemical and physical controls on concentrations of polycyclic aromatic hydrocarbons in water and plankton of the Mediterranean and Black Seas. Global Biogeochem. Cycles 25, 1-14.

Blumer, M., Guillard, R.R.L., Chase, T., 1971. Hydrocarbons of marine phytoplankton. Mar. Biol. 8, 183.

Bouaziz, S., Jedoui, Y., Barrier, E., Angelier, J., 2003. Néotectonique affectant les dépôts marins tyrrhéniens du littoral sud-est tunisien: implications pour les variations du niveau marin. C. R. Géosci. 335, 247-254.

Bouloubassi, I., Saliot, A., 1991. Composition and sources of dissolved and particulate PAH in surface waters from the Rhone delta (NW Mediterranean). Mar. Pollut. Bull. 22, 588594.

Bouloubassi, I., Saliot, A., 1993. Investigation of anthropogenic and natural organic inputs in estuarine sediments using hydrocarbon markers (NAH, LAB, PAH). Oceanol. Act. 16, $145-161$. 
Budzinski, H., Jones, I., Bellocq, J., Pierard, C., Garrigues, P., 1997. Evaluation of sediment contamination by polycyclic aromatic hydrocarbons in the Gironde estuary. Mar. Chem. $58,85-97$.

Castro-Jiménez, J., Berrojalbiz, N., Wollgast, J., Dachs, J., 2012. Polycyclic aromatic hydrocarbons (PAHs) in the Mediterranean Sea: Atmospheric occurrence, deposition and decoupling with settling fluxes in the water column. Environ. Pollut. 166, 40-47.

Chen, J., Henderson, G., Grimm, C.C., Lloyd, S.W., Laine, R.A., 1998. Termites fumigate their nests with naphthalene. Nature 392, 558.

Cincinelli, A., Martellini, T., Bittoni, L., Russo, A., Gambaro, A., Lepri, L., 2008. Natural and anthropogenic hydrocarbons in the water column of the Ross Sea (Antarctica). J. Mar. Syst. 73, 208-220.

Commendatore, M.G., Esteves, J.L., 2004. Natural and anthropogenic hydrocarbons in sediments from the Chubut River (Patagonia, Argentina). Mar. Pollut. Bull. 48, 910-918.

Commendatore, M.G., Nievas, M.L., Amin, O., Esteves, J.L., 2012. Sources and distribution of aliphatic and polyaromatic hydrocarbons in coastal sediments from the Ushuaia Bay (Tierra del Fuego, Patagonia, Argentina). Mar. Environ. Res. 74, 20-31.

Cripps, G.C., 1989. Problems in the identification of anthropogenic hydrocarbons against natural background levels in the Antarctic. Antart. Sci. 1, 307-312.

Dachs, J., Bayona, J.M., Raoux, C., Albaigés, J., 1997. Spatial distribution, vertical profiles and budget of polycyclic aromatic hydrocarbons in western Mediterranean. Env. Sci. Technol. 31, 682-688.

Dachs, J., Lohman, R., Ockenden, W.A., Méjanelle, L., Eisenrich, S., Jones, K.C., 2002. Oceanic biogeochemical controls on global dynamics of persistent organic pollutants. Environ. Sci. Technol. 36, 4229-4237.

Dachs, J., Méjanelle, L., 2010. Organic pollutants in coastal waters, sediments, and biota: A 
relevant driver for ecosystems during the anthropocene? Estuaries and Coasts 33, 1-14.

795

796

797

798

799

800

801

802

803

804

805

806

807

808

809

810

811

812

813

814

815

816

817

818

Delle Site, A., 2001. Factors affecting sorption of organic compounds in natural sorbent/water systems and sorption coefficients for selected pollutants. A review. J. Phys. Chem, 31, 187.

Dong, J., Xia, X., Wang, M., Lai, Y., Zhao, P., Dong, H., Zhao, Y., Wen, J., 2015. Effect of water-sediment regulation of the Xiaolangdi Reservoir on the concentrations, bioavailability, and fluxes of PAHs in the middle and lower reaches of the Yellow River. J. Hydrol. 527, 101-112.

Douglas, A.G., Eglinton, G., 1966. Distribution of Alkanes, in Comparative Phytochemistry. Academic Press: New York, 57-77.

DGEQV (Direction Générale de l'Environnement et de la Qualité de Vie), 2008. Etude de dépollution et de réhabilitation des côtes sud de Sfax. Phase-1: Inventaire et caractérisation des sources de pollution. Note de synthèse. COMETE Engineering, Code 26079, pp. 67.

DGPA, 2010. Direction Générale de Pêche et de l'Aquaculture. Annuaire des statistiques de pêche de Tunisie. D.G.P.A., 144 pp.

D’Ortenzio, F., d'Alcalà, M.R., 2009. On the trophic regimes of the Mediterranean Sea: A satellite analysis. Biogeosciences 6, 139-148.

Drira, Z., Elloumi, J., Guermazi, W., Bel Hassen, M., Hamza, A., Ayadi, H., 2014. Seasonal changes on planktonic diatom communities along an inshore-offshore gradient in the Gulf of Gabes (Tunisia). Acta Ecol. Sin. 34, 34-43.

Drira, Z., Chaari, D., Kmiha-Megdiche, S., Sahnoun, H., Hammami, A., Allouche, N., Tedetti, M., Ayadi, H., 2016. Assessment of anthropogenic inputs in the surface waters of the southern coastal area of Sfax during Spring (Tunisia, Southern Mediterranean Sea). Marine Pollution Bulletin, 104, 355-363.

Elias, V.O., 1997. Even N-Alkane Predominances on the Amazon Shelf and A Northeast Pacific Hydrothermal System. Naturwissenschaften 84, 415-420. 
El Nemr, A., Abd-Allah, A.M. a, 2003. Contamination of polycyclic aromatic hydrocarbons (PAHs) in microlayer and subsurface waters along Alexandria coast, Egypt. Chemosphere $52,1711-6$.

González-Gaya, B., Fernández-Pinos, M.C., Morales, L., Méjanelle, L., Abad, E., Piña, B., Duarte, C.M., Jiménez, B., Dachs, J., 2016. High atmosphere - ocean exchange of semivolatile aromatic hydrocarbons. Nat. Geosci. 9, 438-442.

Goutx, M., and Saliot, A., 1980. Relationship between dissolved and particulate fatty acids and hydrocarbons, chlorophyll and zooplnkton biomass in Villefranche Bay, Mediterranean Sea. Mar. Chem. 8, 299-318.

Gustafsson, O., Gschwend, P.M., Buesseler, K.O., 1997. Using ${ }^{234}$ Th disequilibria to estimate the vertical removal rates of polycyclic aromatic hydrocarbons from the surface ocean. Mar. Chem. 57, 11-23.

Guigue, C., Tedetti, M., Giorgi, S., Goutx, M., 2011. Occurrence and distribution of hydrocarbons in the surface microlayer and subsurface water from the urban coastal marine area off Marseilles, Northwestern Mediterranean Sea. Mar. Pollut. Bull. 62, 2741-2752.

Guigue, C., Tedetti, M., Ferretto, N., Garcia, N., Méjanelle, L., Goutx, M., 2014. Spatial and seasonal variabilities of dissolved hydrocarbons in surface waters from the Northwestern Mediterranean Sea: results from one year intensive sampling. Sci. Total Environ. 466-467, $650-62$.

Guigue, C., Bigot, L., Turquet, J., Tedetti, M., Ferretto, N., Goutx, M., Cuet, P., 2015. Hydrocarbons in a coral reef ecosystem subjected to anthropogenic pressures (La Réunion Island, Indian Ocean). Environ. Chem., 12, 350-365.

Guitart, C., García-Flor, N., Bayona, J.M., Albaigés, J., 2007. Occurrence and fate of polycyclic aromatic hydrocarbons in the coastal surface microlayer. Mar. Pollut. Bull. 54, 186-194. 
Guitart, C., García-Flor, N., Miquel, J.C., Fowler, S.W., Albaigés, J., 2010. Effect of the accumulation of polycyclic aromatic hydrocarbons in the sea surface microlayer on their coastal air-sea exchanges. J. Mar. Sys. 79, 210-217.

Hamdi, I., Denis, M., Bellaaj-Zouari, A., Khemakhem, H., Bel Hassen, M., Hamza, A., Barani, A., Bezac, C., Maalej, S., 2015. The characterisation and summer distribution of ultraphytoplankton in the Gulf of Gabès (Eastern Mediterranean Sea, Tunisia) by using flow cytometry. Cont. Shelf Res. 93, 27-38.

Hattab, T., Ben Rais Lasram, F., Albouy, C., Romdhane, M.S., Jarboui, O., Halouani, G., Cury, P., Le Loc'h, F., 2013. An ecosystem model of an exploited southern Mediterranean shelf region (Gulf of Gabes, Tunisia) and a comparison with other Mediterranean ecosystem model properties. J. Mar. Syst. 128, 159-174.

Hattour, M.J., Sammari, C., Ben Nassrallah, S., 2010. Hydrodynamique du golfe de Gabès déduite à partir des observations de courants et de niveaux. Rev. Paralia 3, 3.1-3.12.

Hinrichsen, D., 1990. Our common seas: Coasts in crisis. Earthscan Publications, London, in association with United Nations Environment Programme, Nairobi, 184 pp.

Institut National de la Météorologie de Tunisie (INM), 2008. Données climatiques et statistiques annuelles des vents. Rapports Annuels (1981-2004), 118pp.

Jabeur, C., Gobert, B., Missaoui, H., 2000. Typologie de la flottille de pêche côtière dans le golfe de Gabès (Tunisie). Aquat. Living Resour. 13, 421-428.

Jedoui, Y., 1980. Etude hydrologique et sédimentologique d'une lagune en domaine méditerranéen: Le bahiret el Boughrara (Tunisie). PhD thesis. Université de Bordeaux I, $190 \mathrm{pp}$.

Jiménez, N., Viñas, M., Guiu-Aragonés, C., Bayona, J., Albaigés, J., Solanas, A., 2011. Polyphasic approach for assessing changes in an autochthonous marine bacterial 
community in the presence of Prestige fuel oil and its biodegradation potential. Appl. Microbiol. Biotechnol., 91, 823-834.

Joliffe, I.T., 1986. Principal component analysis. Springer-Verlag, p. 271.

Karydis, M., Kitsiou, D., 2012. Eutrophication and environmental policy in the Mediterranean Sea: A review. Environ. Monit. Assess. 184, 4931-4984.

Katlane, R., Nechad, B., Ruddick, K., Zargouni, F., 2013. Optical remote sensing of turbidity and total suspended matter in the Gulf of Gabes. Arab. J. Geosci. 6, 1527-1535.

Kennish, M.J., 1992. Poly-nuclear aromatic hydrocarbons. Ecology of estuaries: anthropogenic effects. Boca Raton: CRC Press, p. 133-181.

Kim, S.-J., Kwon, J.-H., 2010. Determination of partition coefficients for selected PAHs between water and dissolved organic matter. Clean - Soil, Air, Water, 38, 797-802.

King, S.M., Leaf, P.A., Olson, A.C., Ray, P.Z., Tarr, M.A., 2014. Photolytic and photocatalytic degradation of surface oil from the Deepwater Horizon spill. Chemosphere, $95,415-422$.

Li, Y., Li, P., Ma, W., Song, Q., Zhou, H., Han, Q., Diao, X., 2015. Spatial and temporal distribution and risk assessment of polycyclic aromatic hydrocarbons in surface seawater from the Haikou Bay, China. Mar. Pollut. Bull. 92, 244-251.

Lipiatou, E., Saliot, A., 1991a. Fluxes and transport of anthropogenic and natural polycyclic aromatic-hydrocarbons in the western Mediterranean Sea. Mar. Chem. 32, 51-71.

Lipiatou, E., Saliot A., 1991b. Hydrocarbon contamination of the Rhone delta and western Mediterranean Sea. Mar. Pollut. Bull. 22, 297-304.

Louati, A., Elleuch, B., Kallel, M., Saliot, A., Dagaut, J., Oudot, J., 2001. Hydrocarbon contamination of coastal sediments from the Sfax area (Tunisia), Mediterranean Sea. Mar. Pollut. Bull. 42, 444-451.

Manodori, L., Gambaro, a., Piazza, R., Ferrari, S., Stortini, a. M., Moret, I., Capodaglio, G., 
2006. PCBs and PAHs in sea-surface microlayer and sub-surface water samples of the Venice Lagoon (Italy). Mar. Pollut. Bull. 52, 184-192.

Marty, J.C., Saliot, A., 1976. Hydrocarbons (normal alkanes) in the surface microlayer of seawater. Deep. Res. Oceanogr. Abstr. 23, 863-873.

May, W.E., Wasik, S.P., Freeman, H.F., 1978. Determination of the solubility behavior of some polycyclic aromatic hydrocarbons in water. Anal. Chem. 50, 997-1000.

Mazurek, M.A., Simoneit, B.R.T., 1984. Characterization of biogenic and petroleum-derived organic matter in aerosols over remote rural and urban areas. In: L.H. Keith (Ed.). Identification and Analysis of Organic Pollutants in Air. Ann Arbor Science/Butterworth. Boston. pp. 353-370.

Mille, G., Asia, L., Guiliano, M., Malleret, L., Doumenq, P., 2007. Hydrocarbons in coastal sediments from the Mediterranean sea (Gulf of Fos area, France). Mar. Pollut. Bull. 54, $566-575$.

Mzoughi, N., Chouba, L., 2011. Distribution and partitioning of aliphatic hydrocarbons and polycyclic aromatic hydrocarbons between water, suspended particulate matter, and sediment in harbours of the West coastal of the Gulf of Tunis (Tunisia). J. Environ. Monit. 13, 689-698.

Neff, J.M., 1979. Polycyclic aromatic hydrocarbons in the aquatic environment sources, fates and biological effects. Applied Science Publishers, LTD, London, p. 262.

Neukermans, G., Ruddick, K., Loisel, H., Roose, P., 2012. Optimization and quality control of suspended particulate matter concentration measurement using turbidity measurements. Limnol. Oceanogr. Methods, 10, 1011-1023.

Pampanin, D.M., Sydnes, M.O., 2013. Polycyclic Aromatic Hydrocarbons a Constituent of Petroleum: Presence and Influence in the Aquatic Environment. In Hydrocarbon, V. Kutcherov (Ed.), ISBN: 978-953-51-0927-3, InTech. 
Pujo-Pay, M., Conan, P., Oriol, L., Cornet-Barthaux, V., Falco, C., Ghiglione, J.F., Goyet, C., Moutin, T., Prieur, L., 2011. Integrated survey of elemental stoichiometry (C, N, P) from the western to eastern Mediterranean Sea. Biogeosciences 8, 883-899.

Raimbault, P., Diaz, F., Pouvesle, W., Boudjellal, B., 1999. Simultaneous determination of particulate forms of organic carbon, nitrogen and phosphorus collected on filters, using a semi-automatic wet-oxidation method. Marine Ecology Progress Series, 180, 289-295.

Raimbault, P., Lantoine, F., Neveux, J., 2004. Dosage rapide de la chlorophylle a et des phéopigments a par fluorimétrie après extraction au méthanol. Comparaison avec la méthode classique d'extraction à l'acétone. Océanis, 30, 189-205.

Readman, J.W., Fillmann, G., Tolosa, I., Bartocci, J., Villeneuve, J.-P., Catinni, C., Mee, L.D., 2002. Petroleum and PAH contamination of the Black Sea. Mar. Pollut. Bull. 44, 4862.

Rekik, A., Drira, Z., Guermazi, W., Elloumi, J., Maalej, S., Aleya, L., Ayadi, H., 2012. Impacts of an uncontrolled phosphogypsum dumpsite on summer distribution of phytoplankton, copepods and ciliates in relation to abiotic variables along the near-shore of the southwestern Mediterranean coast. Mar. Pollut. Bull. 64, 336-46.

Rekik, A., Denis, M., Aleya, L., Maalej, S., Ayadi, H., 2013. Spring plankton community structure and distribution in the north and south coasts of Sfax (Tunisia) after north coast restoration. Mar. Pollut. Bull. 67, 82-93.

Rekik, A., Denis, M., Dugenne, M., Barani, A., Maalej, S., Ayadi, H., 2014. Seasonal distribution of ultraphytoplankton and heterotrophic prokaryotes in relation to abiotic variables on the north coast of Sfax after restoration. Mar. Pollut. Bull. 84, 280-305.

Rieley, G., Collier, R.J., Jones, D.M., Eglinton, G., 1991. The biogeochemistry of Ellesmere Lake, UK-I: source correlation of leaf wax inputs to the sedimentary lipid record. Org. Geochem. 17, 901-912. 
Roose, P., Brinkman, U.A.Th., 2005. Monitoring organic microcontaminants in the marine environment: principles, programmes and progress. Trends Anal. Chem. 24, 897-926.

Sabbah, I., Rebhun, M., Gerstl, Z., 2004. An independent prediction of the effect of dissolved organic matter on the transport of polycyclic aromatic hydrocarbons. J. Contam. Hydrol., $75,55-70$.

Samanta, S.K., Singh, O.V., Jain, R.K., 2002. Polycyclic aromatic hydrocarbons: environmental pollution and bioremediation. Trends Biotechnol. 20, 243-248.

Sammari, C., Koutitonsky, V.G, Moussa, M., 2006. Sea level variability and tidal resonance in the Gulf of Gabes, Tunisia. Continental Shelf Res. 26, 338-350.

Sauret, C., Tedetti, M., Guigue, C., Dumas, C., Lami, R., Pujo-Pay, M., Conan, P., Goutx, M., Ghiglione, J.-F. (2016). Influence of PAHs among other coastal environmental variables on total and PAH-degrading bacterial communities. Environ. Sci. Pollut. Res.

Shi, Z., Tao, S., Pan, B., Liu, W.X., Shen, W.R., 2007. Partitioning and source diagnostics of polycyclic aromatic hydrocarbons in rivers in Tianjin, China 146, 492-500.

Simoneit, B.R.T., Mazurek, M.A., 1982. Organic matter of the troposphere-II.* Natural background of biogenic lipid matter in aerosols over the rural western United States. Atmos. Environ. 16, 2139-2159.

Sohrin, R., and Sempéré R., 2005. Temporal variation in total organic carbon in the Northeast Atlantic in 2000-2001, J. Geophys. Res. 110, C10S90.

Tedetti, M., Guigue, C., Goutx, M., 2010. Utilization of a submersible UV fluorometer for monitoring anthropogenic inputs in the Mediterranean coastal waters. Mar. Pollut. Bull. 60, $350-362$.

Tilseth, S., Solberg, T.S., Westrheim, K., 1984. Sublethal effects of the water-soluble fraction of Ekofisk cll.lde oil on the early larval stages of cod (Gadus morhua L.). Mar. Environ. Res., 11, 1-16. 
The MerMex Group, 2011. Marine ecosystems responses to climatic and anthropogenic forcings in the Mediterranean. Prog. Oceanogr. 91, 97-166.

Tolosa, M., Bayona, O.M., Albaigés, O., 1996. Aliphatic and polycyclic aromatic hydrocarbons and sulfur/oxygen derivatives in Northwestern Mediterranean sediments: Spatial and temporalvariability, fluxes, and budgets. Environ. Sci. Technol. 30, 24952503.

Tornero, V., Hanke, G., 2016. Chemical contaminants entering the marine environment from sea-based sources: A review with a focus on European seas. Mar. Pollut. Bull. 112, 17-38.

Troupin, C., Barth, A., Sirjacobs, D., Ouberdous, M., Brankart, J.-M., Brasseur, P., Rixen, M., Alvera Azcarate, A., Belounis, M., Capet, A., Lenartz, F., Toussaint, M.-E., \& Beckers, J.M., 2012. Generation of analysis and consistent error fields using the Data Interpolating Variational Analysis (Diva). Ocean Model. 52-53, 90-101.

Tsapakis, M., Dakanali, E., Stephanou, E.G., Karakassis, I., 2010. PAHs and n-alkanes in Mediterranean coastal marine sediments: Aquaculture as a significant point source. Journal of Environmental Monitoring 12, 958-963.

UNEP/MAP, 2012. State of the Mediterranean Marine and Coastal Environment, UNEP/MAP-Barcelona Convention, Athens.

Valavanidis, A., Vlachogianni, T., Triantafillaki, S., Dassenakis, M., Androutsos, F., Scoullos, M., 2008. Polycyclic aromatic hydrocarbons in surface seawater and in indigenous mussels (Mytilus galloprovincialis) from coastal areas of the Saronikos Gulf (Greece). Estuar. Coast. Shelf Sci. 79, 733-739.

Vila, J., Nieto, J.M., Mertens, J., Springael, D., Grifoll, M., 2010. Microbial community structure of a heavy fuel oil-degrading marine consortium: linking microbial dynamics with polycyclic aromatic hydrocarbon utilization. FEMS Microbiol. Ecol. 73, 349-362. 
992

993

994

995

996

997

998

999

1000

1001

1002

1003

1004

1005

1006

1007

1008

1009

1010

1011

1012

1013

1014

1015

1016

Volkman, J.K., Holdsworth, D.G., Neil, G.P., Bavor Jr., H.J., 1992. Identification of natural anthropogenic and petroleum hydrocarbons in aquatic sediments. Sci. Tot. Environ. 112, 203-219.

Wang, Z., Fingas, M., Landriault, M., Sigouin, L., Feng, Y., Mullin, J., 1997. Using systematic and comparative analytical data to identify the source of an unknown oil on contaminated birds. J. Chromatogr. A 775, 251-265.

Wang, Z., Fingas, M., Page, D.S., 1999. Oil spill identification. J. Chromatogr. A 843, 369411.

Wang, Z., Fingas, M. V., 2003. Development of oil hydrocarbon fingerprint and identification techniques. Mar. Pollut. Bull. 47, 423-452.

Welschmeyer, N.A., 1994. Fluorometric analysis of chlorophyll $a$ in the presence of chlorophyll $b$ and pheopigments. Limnol. Ocean. 39, 1985-1992.

Wilcke, W., Krauss, M., Amelung, W., 2002. Carbon isotope signature of polycyclic aromatic hydrocarbons (PAHs): evidence for different sources in tropical and temperate environments? Environ. Sci. Technol. 36, 3530-3535.

Wurl, O., Obbard, J.P., 2004. A review of pollutants in the sea-surface microlayer (SML): a unique habitat for marine organisms. Mar. Pollut. Bull. 48, 1016-1030.

Youngblood, W.W., Blumer, M., 1975. Polycyclic aromatic hydrocarbons in the environment: Homologous series in soils and recent marine sediments. Geochim. Cosmochim. Acta 188, 53-55.

Yunker, M.B., Backus, S.M., Graf Pannatier, E., Jeffries, D.S., Macdonald, R.W., 2002. Sources and significance of alkane and PAH hydrocarbons in Canadian arctic rivers. Estuar. Coast. Shelf Sci. 55, 1-31.

Yunker, M.B., Macdonald, R.W., Ross, P.S., Johannessen, S.C., Dangerfield, N., 2015. Alkane and PAH provenance and potential bioavailability in coastal marine sediments 
subject to a gradient of anthropogenic sources in British Columbia, Canada. Org. Geochem. 89-90, 80-116.

Zaghden, H., Kallel, M., Louati, A., Elleuch, B., Oudot, J., Saliot, A., 2005. Hydrocarbons in surface sediments from the Sfax coastal zone, (Tunisia) Mediterranean Sea. Mar. Pollut. Bull. 50, 1287-94.

Zaghden, H., Kallel, M., Elleuch, B., Oudot, J., Saliot, A., 2007. Sources and distribution of aliphatic and polyaromatic hydrocarbons in sediments of Sfax, Tunisia, Mediterranean Sea. Mar. Chem. 105, 70-89.

1025

Zaghden, H., Kallel, M., Elleuch, B., Oudot, J., Saliot, A., Sayadi, S., 2014. Evaluation of hydrocarbon pollution in marine sediments of Sfax coastal areas from the Gabes Gulf of Tunisia, Mediterranean Sea. Environ. Earth Sci. 72, 1073-1082.

Zhou, J.L., Fileman, T.W., Evans, S., Donkin, P., Readman, J.W., Mantoura, R.F.C., Rowland, S., 1999. The partition of fluoranthene and pyrene between suspended particles and surface sediments from Daya Bay, China. Environ. Pollut. 121, 269-81. 


\section{Figure caption}

Figure 1. Location of the study stations in the coastal areas of Sfax and Gabès cities, in the

Gulf of Gabès (Southeastern Mediterranean Sea, Tunisia). The detailed characteristics of the stations are given in Table 1. The six groups of stations (G1-G6) identified according to the hierarchical ascendant classification applied to biogeochemical parameters are presented with different colours.

Figure 2. Box-and-whisker plots of biogeochemical parameters with regard to the six clusters identified from the hierarchical ascendant classification: a) $\mathrm{NO}_{2}{ }^{-}$, b) $\mathrm{NO}_{3}{ }^{-}$, c) $\mathrm{PO}_{4}{ }^{3-}$, d) $\mathrm{Si}(\mathrm{OH})_{4}$, e) TChl $a$, f) Phaeo $a$, g) SPM, h) POC and i) DOC concentrations. The six clusters are as follow: G1 (S2, S6), G2 (S3, S4, S7, S9-S13), G3 (S16, S20, S22), G4 (S17, S18, S21, S23-S26), G5 (S27-S32; S36) and G6 (S33, S34). The black and red lines represent the median and mean values, respectively.

Figure 3. Principal component analysis (PCA) of hydrocarbons dataset: a) correlation circle and b) projections of samples on the first factorial plane (PC1 versus PC2).

Figure 4. Box-and-whisker plots of main hydrocarbon parameters with regard to the three clusters identified from the hierarchical ascendant classification: a) total resolved $n$-alkanes (R), b) Pr/Phy, c) $\mathrm{CPI}_{15-40}$, d) $\sum_{29} \mathrm{PAH}_{-\mathrm{P}+\mathrm{A}}$, e) Alk/Par and f) Flt/(Flt + Pyr). The three clusters are as follow: G'1 (S1-S6, S27-S36), G'2 (S7-S13, S16-S18, S20-S26) and G'3 (S14, S15, S19). The black and red lines represent the median and mean values, respectively.

Figure 5. Spatial distribution of dissolved AH and PAH concentrations in the Sfax and Gabès coastal areas. The three groups of stations identified according to the hierarchical ascendant classification applied to hydrocarbon parameters are presented in black (G'1), red (G'2) and blue (G’3). Ocean Data View software version 4.6.5, Schlitzer, R., http://odv.awi.de, 2014. 
1066 Figure 6. Relative abundances of dissolved AHs (\%) for stations a) S1-S7, S11, S14, S27-

1067 S36, b) S15, S19, c) S8, S17, d) S26, e) S13 and f) S9, S10, S12, S16, S18, S20-S25.

1068 Figure 7. Relative abundances of dissolved PAHs (\%) for stations a) S1-S7, b) S8, c) S9-S13, 1069 d) S14-S20, e) S21-S26 and f) S27-S36.

1070 Figure 8. PAH cross-plot between Flt/(Flt + Pyr) and Ant/(Ant + Phe) ratios. Stations S1, 1071 S13, S29-S31, S35 and S36, for which Ant was not detected, are not represented. 
1072 Table 1. Characteristics of the study stations in the coastal areas of Sfax and Gabès cities, in the Gulf of Gabès (Southeastern Mediterranean Sea,

1073 Tunisia)

1074

\begin{tabular}{|c|c|c|c|c|c|}
\hline Stations & Area & Position & $\begin{array}{l}\text { Date of } \\
\text { sampling }\end{array}$ & $\begin{array}{l}\text { Site depth } \\
\text { (m) }\end{array}$ & $\begin{array}{l}\text { Sampling depth } \\
\text { (m) }\end{array}$ \\
\hline S1 & Northern Sfax, in front of Ezzit wadi & $34^{\circ} 45^{\prime} 34.20^{\prime \prime} \mathrm{N}, 10^{\circ} 48^{\prime} 30.06^{\prime \prime E}$ & $08 / 03 / 2015$ & 0.5 & 0.1 \\
\hline $\mathrm{S} 2$ & Northern Sfax, in front of Ezzit wadi & $34^{\circ} 45^{\prime} 29.31^{\prime \prime} \mathrm{N}, 10^{\circ} 48^{\prime} 38.11^{\prime \prime E}$ & $23 / 10 / 2014$ & 0.9 & 0.1 \\
\hline S3 & Northern Sfax, in front of Ezzit wadi & $34^{\circ} 45^{\prime} 04.18^{\prime \prime} \mathrm{N}, 10^{\circ} 49^{\prime} 05.26^{\prime \prime} \mathrm{E}$ & $23 / 10 / 2014$ & 1.2 & 0.1 \\
\hline S4 & Northern Sfax, in front of Ezzit wadi & $34^{\circ} 44^{\prime} 40.06^{\prime \prime} \mathrm{N}, 10^{\circ} 49^{\prime} 30.42^{\prime \prime} \mathrm{E}$ & $23 / 10 / 2014$ & 1.8 & 0.1 \\
\hline S5 & Northern Sfax, in front of Taparura fishing harbour & $34^{\circ} 45^{\prime} 16.47^{\prime \prime} \mathrm{N}, 10^{\circ} 47^{\prime} 55.98^{\prime \prime} \mathrm{E}$ & $08 / 03 / 2015$ & 0.5 & 0.1 \\
\hline S6 & Northern Sfax, in front of Taparura fishing harbour & $34^{\circ} 45^{\prime} 12.08^{\prime \prime} \mathrm{N}, 10^{\circ} 48^{\prime} 01.54^{\prime \prime} \mathrm{E}$ & $23 / 10 / 2014$ & 2 & 0.1 \\
\hline S7 & Northern Sfax, in front of Taparura fishing harbour & $34^{\circ} 44^{\prime} 50.57^{\prime \prime} \mathrm{N}, 10^{\circ} 48^{\prime} 33.99^{\prime \prime} \mathrm{E}$ & $23 / 10 / 2014$ & 2 & 0.1 \\
\hline S8 & Northern Sfax, in front of PK4 channel & $34^{\circ} 44^{\prime} 57.08^{\prime \prime} \mathrm{N}, 10^{\circ} 47^{\prime} 20.72^{\prime \prime} \mathrm{E}$ & $08 / 03 / 2015$ & 0.5 & 0.1 \\
\hline S9 & Northern Sfax, in front of PK4 channel & $34^{\circ} 44^{\prime} 48.13^{\prime \prime} \mathrm{N}, 10^{\circ} 47^{\prime} 28.79^{\prime \prime} \mathrm{E}$ & $23 / 10 / 2014$ & 1.2 & 0.1 \\
\hline S10 & Northern Sfax, in front of PK4 channel & $34^{\circ} 44^{\prime} 25.94^{\prime \prime} \mathrm{N}, 10^{\circ} 48^{\prime} 02.75^{\prime \prime} \mathrm{E}$ & $23 / 10 / 2014$ & 2 & 0.1 \\
\hline S11 & Northern Sfax, in front of PK4 channel & $34^{\circ} 44^{\prime} 06.98^{\prime \prime} \mathrm{N}, 10^{\circ} 48^{\prime} 30.00^{\prime \prime} \mathrm{E}$ & $23 / 10 / 2014$ & 1 & 0.1 \\
\hline S12 & Northern Sfax, in front of buried phosphogypsum & $34^{\circ} 44^{\prime} 11.50^{\prime \prime} \mathrm{N}, 10^{\circ} 47^{\prime} 17.78^{\prime \prime} \mathrm{E}$ & $23 / 10 / 2014$ & 2 & 0.1 \\
\hline S13 & Northern Sfax, in front of buried phosphogypsum & $34^{\circ} 43^{\prime} 54.81^{\prime \prime} \mathrm{N}, 10^{\circ} 47^{\prime} 49.23^{\prime \prime} \mathrm{E}$ & $23 / 10 / 2014$ & 2 & 0.1 \\
\hline S14 & Southern Sfax, in front of commercial harbour & $34^{\circ} 43^{\prime} 15.18^{\prime \prime} \mathrm{N}, 10^{\circ} 46^{\prime} 55.91 " \mathrm{E}$ & $08 / 03 / 2015$ & 0.5 & 0.1 \\
\hline S15 & Southern Sfax, between commercial and fishing harbours & $34^{\circ} 42^{\prime} 53.31^{\prime \prime} \mathrm{N}, 10^{\circ} 46^{\prime} 36.94^{\prime \prime} \mathrm{E}$ & $08 / 03 / 2015$ & 0.5 & 0.1 \\
\hline S16 & Southern Sfax, in front of fishing harbour & $34^{\circ} 42^{\prime} 33.58^{\prime \prime} \mathrm{N}, 10^{\circ} 46^{\prime} 10.56^{\prime \prime} \mathrm{E}$ & $18 / 10 / 2014$ & 3 & 0.1 \\
\hline S17 & Southern Sfax, in front of fishing harbour & $34^{\circ} 42^{\prime} 13.32^{\prime \prime} \mathrm{N}, 10^{\circ} 46^{\prime} 43.64^{\prime \prime} \mathrm{E}$ & $18 / 10 / 2014$ & 5 & 0.1 \\
\hline S18 & Southern Sfax, in front of fishing harbour & $34^{\circ} 41^{\prime} 55.94^{\prime \prime} \mathrm{N}, 10^{\circ} 47^{\prime} 17.71^{\prime \prime} \mathrm{E}$ & $18 / 10 / 2014$ & 9 & 0.1 \\
\hline S19 & Southern Sfax, in front of Sidi Salem channel/industrial zone & $34^{\circ} 42^{\prime} 32.34^{\prime \prime} \mathrm{N}, 10^{\circ} 45^{\prime} 22.38^{\prime \prime} \mathrm{E}$ & $08 / 03 / 2015$ & 0.5 & 0.1 \\
\hline S20 & Southern Sfax, in front of Sidi Salem channel/industrial zone & $34^{\circ} 42^{\prime} 15.90^{\prime \prime} \mathrm{N}, 10^{\circ} 45^{\prime} 54.53^{\prime \prime} \mathrm{E}$ & $18 / 10 / 2014$ & 1 & 0.1 \\
\hline S21 & Southern Sfax, in front of Sidi Salem channel/industrial zone & $34^{\circ} 41^{\prime} 58.75^{\prime \prime} \mathrm{N}, 10^{\circ} 46^{\prime} 30.02^{\prime \prime} \mathrm{E}$ & $18 / 10 / 2014$ & 6 & 0.1 \\
\hline $\mathrm{S} 22$ & Southern Sfax, in front of El Maou wadi/SIAPE phosphogysum area & $34^{\circ} 41^{\prime} 35.05^{\prime \prime} \mathrm{N}, 10^{\circ} 45^{\prime} 25.26^{\prime \prime} \mathrm{E}$ & $18 / 10 / 2014$ & 1 & 0.1 \\
\hline S23 & Southern Sfax, in front of El Maou wadi/SIAPE phosphogysum area & $34^{\circ} 41^{\prime} 22.70^{\prime \prime} \mathrm{N}, 10^{\circ} 46^{\prime} 01.65^{\prime \prime} \mathrm{E}$ & $18 / 10 / 2014$ & 8 & 0.1 \\
\hline S24 & Southern Sfax, in front of El Maou wadi/SIAPE phosphogysum area & $34^{\circ} 41^{\prime} 08.60^{\prime \prime} \mathrm{N}, 10^{\circ} 46^{\prime} 37.37^{\prime \prime} \mathrm{E}$ & $18 / 10 / 2014$ & 6.2 & 0.1 \\
\hline S25 & Southern Sfax, in front of El Hakmouni wadi/SIAPE phosphogysum area & $34^{\circ} 40^{\prime} 40.42^{\prime \prime} \mathrm{N}, 10^{\circ} 45^{\prime} 00.41^{\prime \prime} \mathrm{E}$ & $18 / 10 / 2014$ & 4 & 0.1 \\
\hline S26 & Southern Sfax, in front of El Hakmouni wadi/SIAPE phosphogysum area & $34^{\circ} 40^{\prime} 25.81^{\prime \prime} \mathrm{N}, 10^{\circ} 45^{\prime} 37.67^{\prime \prime} \mathrm{E}$ & $18 / 10 / 2014$ & 5.5 & 0.1 \\
\hline S27 & Gabès, in front of El-Tine wadi & $33^{\circ} 56^{\prime} 17.26^{\prime \prime} \mathrm{N}, 10^{\circ} 05^{\prime} 09.35^{\prime \prime} \mathrm{E}$ & $13 / 11 / 2014$ & 5.5 & 0.1 \\
\hline S28 & Gabès, in front of El-Tine wadi & $33^{\circ} 56^{\prime} 25.23^{\prime \prime} \mathrm{N}, 10^{\circ} 05^{\prime} 47.31^{\prime \prime} \mathrm{E}$ & $13 / 11 / 2014$ & 8.5 & 0.1 \\
\hline S29 & Gabès, in front of El-Tine wadi & $33^{\circ} 56^{\prime} 32.81^{\prime \prime} \mathrm{N}, 10^{\circ} 06^{\prime} 25.37^{\prime \prime} \mathrm{E}$ & $13 / 11 / 2014$ & 10 & 0.1 \\
\hline S30 & Gabès, in front of commercial harbour and phosphogysum discharges & $33^{\circ} 55^{\prime} 03.65^{\prime \prime} \mathrm{N}, 10^{\circ} 06^{\prime} 25.72^{\prime \prime} \mathrm{E}$ & $13 / 11 / 2014$ & 8 & 0.1 \\
\hline S31 & Gabès, in front of commercial harbour and phosphogysum discharges & $33^{\circ} 55^{\prime} 16.48^{\prime \prime} \mathrm{N}, 10^{\circ} 07^{\prime} 01.99^{\prime \prime} \mathrm{E}$ & $13 / 11 / 2014$ & 9.5 & 0.1 \\
\hline
\end{tabular}


S32 Gabès, in front of commercial harbour and phosphogysum discharges

S33 Gabès, between commercial and fishing harbours

S34 Gabès, between commercial and fishing harbours

S35 Gabès, in front of fishing harbour and Gabès wadi

S36 $33^{\circ} 55^{\prime} 27.79^{\prime \prime} \mathrm{N}, 10^{\circ} 07^{\prime} 36.81^{\prime \prime} \mathrm{E}$ $33^{\circ} 54^{\prime} 24.48^{\prime \prime} \mathrm{N}, 10^{\circ} 06^{\prime} 37.27^{\prime \prime} \mathrm{E}$

$33^{\circ} 54 ' 37.77^{\prime \prime} \mathrm{N}, 10^{\circ} 07^{\prime} 13.43 " \mathrm{E}$

$33^{\circ} 53^{\prime} 50.15^{\prime \prime} \mathrm{N}, 10^{\circ} 07^{\prime} 20.52^{\prime \prime} \mathrm{E}$

$33^{\circ} 54^{\prime} 06.24^{\prime \prime} \mathrm{N}, 10^{\circ} 07^{\prime} 55.26 " \mathrm{E}$
$13 / 11 / 2014$

$13 / 11 / 2014$

$13 / 11 / 2014$

$13 / 11 / 2014$

$13 / 11 / 2014$

\section{5 \\ 1076 \\ 1077 \\ 1078 \\ 1079 \\ 1080 \\ 1081 \\ 1082 \\ 1083 \\ 1084 \\ 1085 \\ 1086 \\ 1087 \\ 1088 \\ 1089 \\ 1090 \\ 1091 \\ 1092 \\ 1093}


Table 2. Physical and biogeochemical parameters.

1095

\begin{tabular}{|c|c|c|c|c|c|c|c|c|c|c|c|c|}
\hline Stations & $\mathrm{T}\left({ }^{\circ} \mathrm{C}\right)$ & Salinity & $\mathrm{pH}$ & $\begin{array}{l}\mathrm{NO}_{2}^{-} \\
(\mu \mathrm{M}) \\
\end{array}$ & $\begin{array}{l}\mathrm{NO}_{3}^{-} \\
(\mu \mathrm{M}) \\
\end{array}$ & $\begin{array}{l}\mathrm{PO}_{4}^{3-} \\
(\mu \mathrm{M})\end{array}$ & $\begin{array}{l}\mathrm{Si}(\mathrm{OH})_{4} \\
(\mu \mathrm{M})\end{array}$ & $\begin{array}{l}\text { TChl } a \\
\left(\mu \mathrm{g} \mathrm{L}^{-1}\right)\end{array}$ & $\begin{array}{l}\text { Phae } a \\
\left(\mu \mathrm{g} \mathrm{L}^{-1}\right)\end{array}$ & $\begin{array}{l}\text { SPM } \\
\left(\mathrm{mg} \mathrm{L}^{-1}\right)\end{array}$ & $\begin{array}{l}\text { POC } \\
(\mu \mathrm{M})\end{array}$ & $\begin{array}{l}\text { DOC } \\
(\mu \mathrm{M})\end{array}$ \\
\hline S1 & $n d$ & $N d$ & 8.30 & $n d$ & $n d$ & $n d$ & $n d$ & $n d$ & $n d$ & $n d$ & $n d$ & $n d$ \\
\hline $\mathrm{S} 2$ & 21.0 & 42 & 8.11 & 0.24 & 0.11 & 6.2 & 8.5 & 16.1 & 2.8 & 43.6 & 244.8 & 180.8 \\
\hline S3 & 21.8 & 42 & 8.19 & 0.06 & 0.06 & 7.5 & 6.1 & 5.7 & 1.7 & 16.5 & 53.2 & 148.3 \\
\hline S4 & 21.0 & 42 & 8.14 & 0.10 & 0.09 & 7.8 & 6.0 & 5.3 & 0.6 & 13.4 & 43.5 & 144.9 \\
\hline S5 & $n d$ & $N d$ & 8.12 & $n d$ & $n d$ & nd & $n d$ & $n d$ & nd & $n d$ & nd & $n d$ \\
\hline S6 & 21.5 & 42 & 8.06 & 0.07 & 0.18 & 9.7 & 8.1 & 6.0 & 3.4 & 59.4 & 207.6 & 139.7 \\
\hline S7 & 22.0 & 40 & 8.21 & 0.04 & 0.12 & 8.6 & 5.1 & 2.3 & 0.6 & 9.7 & 30.3 & 129.1 \\
\hline S8 & $n d$ & $N d$ & 8.17 & $n d$ & $n d$ & $n d$ & $n d$ & $n d$ & nd & $n d$ & nd & 106.7 \\
\hline S9 & 22.5 & 42 & 8.11 & 0.05 & 0.26 & 11.6 & 4.1 & 2.9 & 1.4 & 17.6 & 66.5 & 122.2 \\
\hline S10 & 22.6 & 40 & 8.14 & 0.03 & 0.13 & 10.0 & 4.0 & 1.7 & 0.7 & 23.3 & 28.2 & 122.1 \\
\hline S11 & 22.0 & 38 & 8.14 & 0.07 & 0.17 & 9.4 & 6.9 & 3.1 & 2.2 & 25.8 & 101.8 & 135.2 \\
\hline S12 & 23.2 & 42 & 8.01 & 0.07 & 0.50 & 14.7 & 4.3 & 4.1 & 2.0 & 16.4 & 45.3 & 146.8 \\
\hline S13 & 21.5 & 40 & 8.00 & 0.07 & 0.29 & 11.9 & 3.1 & 2.9 & 0.6 & 15.7 & 23.6 & 124.1 \\
\hline S14 & $n d$ & $N d$ & 8.08 & $n d$ & $n d$ & $n d$ & $n d$ & $n d$ & $n d$ & $n d$ & $n d$ & $n d$ \\
\hline S15 & $n d$ & $N d$ & 8.22 & $n d$ & $n d$ & $n d$ & $n d$ & $n d$ & $n d$ & $n d$ & $n d$ & 115.0 \\
\hline S16 & 26.7 & 40 & 8.02 & 0.68 & 1.50 & 120.0 & 13.4 & 40.7 & 9.7 & 27.1 & 177.5 & 190.9 \\
\hline S17 & 26.5 & 40 & 8.03 & 0.00 & 0.06 & 17.4 & 2.5 & 7.7 & 3.8 & 11.8 & 49.4 & 127.3 \\
\hline S18 & 27.3 & 40 & 7.94 & 0.01 & 0.07 & 5.5 & 1.4 & 2.0 & 0.4 & 10.6 & 14.9 & 107.3 \\
\hline S19 & $n d$ & $N d$ & 8.19 & $n d$ & $n d$ & $n d$ & $n d$ & $n d$ & $n d$ & $n d$ & $n d$ & 132.1 \\
\hline S20 & 26.9 & 40 & 8.06 & 0.90 & 1.76 & 120.3 & 7.3 & 29.0 & 7.8 & 32.2 & 168.2 & 186.6 \\
\hline S21 & 26.5 & 38 & 8.00 & 0.23 & 0.86 & 24.0 & 3.2 & 8.7 & 2.4 & 13.0 & 42.4 & 126.3 \\
\hline S22 & 26.9 & 32 & 8.11 & 0.66 & 1.20 & 82.1 & 7.2 & 13.8 & 3.0 & 19.5 & 77.0 & 206.9 \\
\hline $\mathrm{S} 23$ & 26.8 & 38 & 8.00 & 0.15 & 0.45 & 6.4 & 2.8 & 2.8 & 0.8 & 9.0 & 24.7 & 126.2 \\
\hline S24 & 26.9 & 40 & 7.90 & 0.01 & 0.09 & 10.2 & 2.3 & 3.2 & 1.0 & 8.3 & 17.0 & 121.1 \\
\hline S25 & 26.7 & 35 & 7.90 & 0.35 & 1.31 & 14.5 & 5.3 & 3.9 & 2.5 & 10.1 & 30.5 & 126.2 \\
\hline S26 & 26.8 & 38 & 7.94 & 0.16 & 0.47 & 12.0 & 4.6 & 4.9 & 1.9 & 8.8 & 35.7 & 117.4 \\
\hline S27 & 22.0 & 36 & 7.97 & 0.02 & 0.89 & 18.7 & 13.1 & 6.1 & 1.7 & 17.0 & 34.1 & 137.4 \\
\hline S28 & 22.0 & 35 & 7.99 & 0.01 & 0.31 & 14.9 & 11.2 & 5.7 & 1.7 & 19.5 & 34.6 & 110.6 \\
\hline S29 & 21.0 & 32 & 8.14 & 0.00 & 0.01 & 6.8 & 2.6 & 3.0 & 0.7 & 18.7 & 24.5 & 112.9 \\
\hline S30 & 20.0 & 32 & 8.08 & 0.00 & 0.97 & 19.9 & 15.2 & 7.1 & 1.1 & 21.8 & 36.8 & 217.6 \\
\hline
\end{tabular}




\begin{tabular}{|c|c|c|c|c|c|c|c|c|c|c|c|c|}
\hline S31 & 20.0 & 34 & 8.00 & 0.00 & 0.14 & 14.1 & 7.9 & 6.7 & 1.2 & 22.7 & 39.1 & 124.3 \\
\hline S32 & 21.0 & 35 & 8.02 & 0.00 & 0.01 & 15.0 & 8.1 & 8.1 & 2.1 & 22.2 & 45.1 & 122.8 \\
\hline S33 & 18.0 & 36 & 7.97 & 0.00 & 4.00 & 42.1 & 33.4 & 7.7 & 1.4 & 19.5 & 46.2 & 110.6 \\
\hline S34 & 18.0 & 38 & 8.02 & 0.03 & 3.22 & 35.9 & 27.6 & 8.7 & 1.6 & 19.3 & 54.8 & 118.9 \\
\hline S35 & 18.0 & 40 & 8.13 & 0.00 & 0.39 & 12.1 & 6.6 & 5.0 & 1.5 & 21.9 & 36.8 & 127.8 \\
\hline S36 & 18.0 & 39 & 8.13 & 0.00 & 1.47 & 21.8 & 14.9 & 6.5 & 1.6 & 18.8 & 54.4 & 187.1 \\
\hline
\end{tabular}

1096

$n d$ : not determined. $\mathrm{NO}_{2}{ }^{-}:$nitrites; $\mathrm{NO}_{3}{ }^{-}$: nitrates; $\mathrm{PO}_{4}{ }^{3-}:$ phosphates; $\mathrm{Si}(\mathrm{OH})_{4}:$ silicates; TChl $a$ : total chlorophyll $a$; Phae $a$ : phaeopigment $a$;

POC: particulate organic carbon; SPM: suspended particulate matter; DOC: dissolved organic carbon.

1098

1099

1100

1101

1102

1103

1104

1105

1106

1107

1108

1109

1110

1111 
1115 Table 3. Dissolved aliphatic hydrocarbons (AHs) and polycyclic aromatic hydrocarbons (PAHs): concentrations and ratios.

\begin{tabular}{|c|c|c|c|c|c|c|c|c|c|c|c|c|}
\hline & $R\left(\mu \mathrm{g} \mathrm{L}^{-1}\right)$ & $\mathrm{UCM}\left(\mu \mathrm{g} \mathrm{L}^{-1}\right)$ & $R / \mathrm{UCM}$ & Pr/Phy & $\mathrm{CPI}_{-15-40}$ & $\mathrm{MH}$ & $\begin{array}{l}\sum_{16} \mathrm{PAH} \\
\left(\mathrm{ng} \mathrm{L} \mathrm{L}^{-1}\right)\end{array}$ & $\begin{array}{l}\sum_{19} \mathrm{PAH}_{-\mathrm{P}} \\
\left(\mathrm{ng} \mathrm{L}^{-1}\right)\end{array}$ & $\begin{array}{l}\sum_{29} \mathrm{PAH}_{-\mathrm{P}+\mathrm{A}} \\
\left(\mathrm{ng} \mathrm{L^{-1 } )}\right.\end{array}$ & $\mathrm{Alk} / \mathrm{Par}$ & $\begin{array}{l}\text { Ant/ } \\
(\text { Ant }+ \text { Phe })\end{array}$ & $\begin{array}{l}\text { Flt/ } \\
(\text { Flt }+ \text { Pyr })\end{array}$ \\
\hline $\mathrm{S} 1$ & 4.46 & 7.95 & 0.56 & 0.32 & 0.99 & $n-\mathrm{C}_{25}-\mathrm{C}_{26}$ & 6.25 & 6.25 & 34.84 & 4.58 & nd & 0.08 \\
\hline $\mathrm{S} 2$ & 5.34 & 5.42 & 0.99 & 0.34 & 0.96 & $n-\mathrm{C}_{25}-\mathrm{C}_{26}$ & 12.73 & 12.98 & 27.88 & 1.15 & 0.05 & 0.21 \\
\hline S3 & 5.88 & $N p$ & $n d$ & 0.27 & 1.05 & $n-\mathrm{C}_{25}-\mathrm{C}_{26}$ & 10.39 & 10.51 & 17.16 & 0.63 & 0.04 & 0.21 \\
\hline S4 & 6.31 & 7.96 & 0.79 & 0.34 & 1 & $n-\mathrm{C}_{25}-\mathrm{C}_{26}$ & 10.66 & 10.80 & 19.52 & 0.81 & 0.02 & 0.21 \\
\hline S5 & 4.93 & 8.30 & 0.59 & 0.33 & 0.97 & $n-\mathrm{C}_{25}-\mathrm{C}_{26}$ & 7.58 & 7.58 & 37.67 & 3.97 & 0.78 & 0.10 \\
\hline S6 & 3.84 & $N p$ & $n d$ & 0.36 & 0.98 & $n-\mathrm{C}_{25}-\mathrm{C}_{26}$ & 7.90 & 8.08 & 18.14 & 1.24 & 0.03 & 0.20 \\
\hline S7 & 1.09 & $N p$ & nd & 0.51 & 1.09 & $n-\mathrm{C}_{25}-\mathrm{C}_{26}$ & 10.89 & 11.08 & 20.23 & 0.83 & 0.04 & 0.19 \\
\hline S8 & 0.033 & $N p$ & $n d$ & 1.02 & 1.30 & $n-\mathrm{C}_{29}$ & 14.50 & 14.50 & 45.21 & 2.12 & 0.75 & 0.91 \\
\hline S9 & 0.030 & $N p$ & $n d$ & 1.13 & 0.31 & $n-\mathrm{C}_{16}-\mathrm{C}_{18}$ & 8.38 & 8.64 & 24.58 & 1.84 & 0.05 & 0.57 \\
\hline S10 & 0.021 & $N p$ & $n d$ & 0.97 & 0.49 & $n-\mathrm{C}_{16}-\mathrm{C}_{18}$ & 3.69 & 3.79 & 9.86 & 1.6 & 0.07 & 0.58 \\
\hline S11 & 0.144 & $N p$ & $n d$ & 0.79 & 0.93 & $n-\mathrm{C}_{25}-\mathrm{C}_{26}$ & 4.44 & 4.50 & 9.73 & 1.16 & 0.08 & 0.40 \\
\hline S12 & 0.045 & $N p$ & $n d$ & 1.06 & 0.41 & $n-\mathrm{C}_{16}$ & 16.67 & 17.45 & 53.70 & 2.08 & 0.04 & 0.55 \\
\hline S13 & 0.053 & $N p$ & nd & 1.51 & 0.97 & $n-\mathrm{C}_{33}$ & 3.53 & 3.63 & 8.94 & 1.46 & $n d$ & 0.51 \\
\hline S14 & 4.51 & 7.41 & 0.61 & 0.34 & 0.97 & $n-\mathrm{C}_{25}-\mathrm{C}_{26}$ & 19.52 & 19.52 & 156.82 & 7.03 & 0.80 & 0.13 \\
\hline S15 & 0.044 & $N p$ & $n d$ & 0.43 & 0.94 & $n-\mathrm{C}_{17}$-Phy & 25.65 & 25.65 & 197.83 & 6.71 & 0.79 & 0.10 \\
\hline S16 & 0.041 & $N p$ & $n d$ & 1.57 & 0.89 & $n-\mathrm{C}_{15}-\mathrm{C}_{16}$ & 7.66 & 8.08 & 26.25 & 2.25 & 0.08 & 0.56 \\
\hline S17 & 0.094 & $N p$ & $n d$ & 1.73 & 0.86 & $n-\mathrm{C}_{29}$ & 5.68 & 6.00 & 19.41 & 2.23 & 0.05 & 0.53 \\
\hline S18 & 0.16 & $N p$ & $n d$ & 1.51 & 0.11 & $n-\mathrm{C}_{16}$ & 7.42 & 7.71 & 19.84 & 1.57 & 0.03 & 0.61 \\
\hline S19 & 0.035 & $N p$ & $n d$ & 0.48 & 0.99 & $n-\mathrm{C}_{17}$-Phy & 24.90 & 24.90 & 172.76 & 5.94 & 0.78 & 0.08 \\
\hline $\mathrm{S} 20$ & 0.25 & $N p$ & $n d$ & 0.90 & 0.14 & $n-\mathrm{C}_{16}-\mathrm{C}_{18}$ & 7.79 & 8.29 & 25.97 & 2.13 & 0.05 & 0.49 \\
\hline S21 & 0.034 & $N p$ & $n d$ & 2.43 & 0.59 & $n-\mathrm{C}_{16}$ & 19.65 & 20.33 & 37.29 & 0.83 & 0.03 & 0.88 \\
\hline $\mathrm{S} 22$ & 0.077 & $N p$ & $n d$ & 1.25 & 0.33 & $n-\mathrm{C}_{16}$ & 13.59 & 14.30 & 37.85 & 1.65 & 0.04 & 0.78 \\
\hline $\mathrm{S} 23$ & 0.038 & $N p$ & $n d$ & 1.64 & 0.53 & $n-\mathrm{C}_{16}$ & 18.84 & 19.21 & 30.13 & 0.57 & 0.02 & 0.85 \\
\hline $\mathrm{S} 24$ & 0.026 & $N p$ & $n d$ & 1.76 & 0.52 & $n-\mathrm{C}_{16}$ & 9.98 & 10.40 & 22.79 & 1.19 & 0.03 & 0.74 \\
\hline $\mathrm{S} 25$ & 0.032 & $N p$ & $n d$ & 1.66 & 0.42 & $n-\mathrm{C}_{16}$ & 53.73 & 56.37 & 70.60 & 0.25 & 0.04 & 0.86 \\
\hline S26 & 0.045 & $N p$ & $n d$ & 1.85 & 0.62 & $n-\mathrm{C}_{16}$ & 18.24 & 19.08 & 29.26 & 0.53 & 0.02 & 0.84 \\
\hline $\mathrm{S} 27$ & 4.66 & 12.03 & 0.39 & 0.29 & 0.99 & $n-\mathrm{C}_{26}-\mathrm{C}_{25}$ & 6.63 & 6.63 & 37.49 & 4.66 & 0.31 & 0.14 \\
\hline S28 & 4.53 & 7.37 & 0.61 & 0.35 & 0.91 & $n-\mathrm{C}_{26}-\mathrm{C}_{25}$ & 6.36 & 6.36 & 39.40 & 5.2 & 0.62 & 0.12 \\
\hline S29 & 4.41 & 7.32 & 0.60 & 0.30 & 0.96 & $n-\mathrm{C}_{26}-\mathrm{C}_{25}$ & 4.03 & 4.03 & 15.48 & 2.84 & $n d$ & 0.06 \\
\hline $\mathrm{S} 30$ & 4.92 & 8.34 & 0.59 & 0.36 & 0.98 & $n-\mathrm{C}_{26}-\mathrm{C}_{25}$ & 6.07 & 6.07 & 24.09 & 2.97 & $n d$ & 0.19 \\
\hline S31 & 4.28 & 8.13 & 0.53 & 0.35 & 0.99 & $n-\mathrm{C}_{26}-\mathrm{C}_{25}$ & 4.23 & 4.23 & 16.56 & 2.91 & $n d$ & 0.09 \\
\hline
\end{tabular}




\begin{tabular}{llllllllllll} 
S32 & 4.44 & 7.89 & 0.56 & 0.34 & 0.98 & $n-\mathrm{C}_{26}-\mathrm{C}_{25}$ & 6.37 & 6.37 & 29.24 & 3.6 & 0.38 \\
S33 & 3.61 & 6.53 & 0.55 & 0.36 & 0.98 & $n-\mathrm{C}_{26}-\mathrm{C}_{25}$ & 7.33 & 7.33 & 47.42 & 5.47 & 0.40 \\
S34 & 5.08 & 14.03 & 0.36 & 0.31 & 0.95 & $n-\mathrm{C}_{26}-\mathrm{C}_{25}$ & 9.38 & 9.38 & 56.79 & 5.05 & 0.22 \\
S35 & 4.38 & 7.47 & 0.59 & 0.32 & 0.99 & $n-\mathrm{C}_{26}-\mathrm{C}_{25}$ & 5.09 & 5.09 & 20.45 & 3.02 & $n d$ \\
S36 & 3.91 & 7.05 & 0.55 & 0.31 & 0.98 & $n-\mathrm{C}_{26}-\mathrm{C}_{25}$ & 7.25 & 7.25 & 33.10 & 3.56 & $n d$ \\
\hline
\end{tabular}

$1116 \quad n p$ : not present; $n d$ : not determined. $R$ : total resolved $n$-alkanes from $n-\mathrm{C}_{15}$ to $n$ - $\mathrm{C}_{40}$ including two isoprenoids, pristane (Pr) and phytane (Phy); UCM:

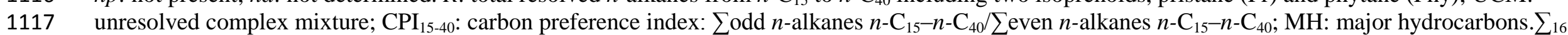

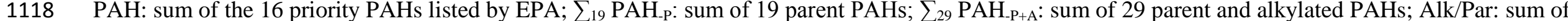

1119 alkylated PAHs/sum of parent PAHs; Ant: anthracene; Phe: phenanthrene; Flt: fluoranthene; Pyr: pyrene. 
1136 Table 4. Spearman's rank-order correlation matrix for biogeochemical parameters and dissolved hydrocarbons $(\mathrm{n}=30)$.

1137

\begin{tabular}{|c|c|c|c|c|c|c|c|c|c|c|c|c|c|}
\hline & $\mathrm{T}\left({ }^{\circ} \mathrm{C}\right)$ & Salinity & $\mathrm{pH}$ & $\mathrm{NO}_{2}^{-}$ & $\mathrm{NO}_{3}^{-}$ & $\mathrm{PO}_{4}^{3-}$ & $\overline{\mathrm{Si}(\mathrm{OH})_{4}}$ & TChl $a$ & Phae $a$ & SPM & $\overline{P O C}$ & $\overline{\text { DOC }}$ & $R$ \\
\hline $\begin{array}{l}\text { Salinity } \\
\text { nat }\end{array}$ & 0.09 & & & & & & & & & & & & \\
\hline $\mathrm{pH}$ & -0.35 & 0.32 & & & & & & & & & & & \\
\hline $\mathrm{NO}_{2}^{-}$ & 0.54 & 0.30 & -0.04 & & & & & & & & & & \\
\hline $\mathrm{NO}_{3}^{-}$ & 0.00 & -0.26 & -0.30 & 0.31 & & & & & & & & & \\
\hline $\mathrm{PO}_{4}^{3-}$ & -0.03 & -0.37 & -0.25 & 0.03 & 0.74 & & & & & & & & \\
\hline $\mathrm{Si}(\mathrm{OH})_{4}$ & -0.56 & -0.24 & 0.07 & -0.06 & 0.54 & 0.53 & & & & & & & \\
\hline TChl $a$ & -0.18 & -0.16 & -0.05 & 0.17 & 0.41 & 0.70 & 0.65 & & & & & & \\
\hline Phae $a$ & 0.23 & 0.04 & -0.07 & 0.47 & 0.32 & 0.50 & 0.33 & 0.69 & & & & & \\
\hline SPM & -0.18 & 0.29 & 0.36 & 0.34 & 0.27 & 0.36 & 0.56 & 0.69 & 0.72 & & & & \\
\hline POC & -0.39 & 0.00 & 0.37 & 0.01 & 0.15 & 0.25 & 0.63 & 0.49 & 0.41 & 0.64 & & & \\
\hline DOC & -0.03 & 0.23 & 0.45 & 0.38 & 0.24 & 0.25 & 0.36 & 0.46 & 0.45 & 0.56 & 0.35 & & \\
\hline$R$ & -0.68 & -0.06 & 0.33 & -0.32 & -0.16 & -0.06 & 0.56 & 0.35 & -0.08 & 0.22 & 0.32 & 0.20 & \\
\hline$\sum_{29} \mathrm{PAH}_{-\mathrm{P}+\mathrm{A}}$ & 0.09 & -0.30 & -0.47 & 0.22 & 0.66 & 0.55 & 0.39 & 0.40 & 0.34 & 0.15 & -0.15 & 0.01 & $-0.07^{*}$ \\
\hline
\end{tabular}

Significant correlations $(\mathrm{p}<0.05)$ are in bold. Stations S1, S5, S8, S14, S15 and S19 are not included in these correlations (absence of biogeochemical parameter measurements). * For the correlation between $R$ and $\sum_{29} \mathrm{PAH}_{\mathrm{P}+\mathrm{A}}$ all stations are taken into account (i.e., $\mathrm{n}=36$ ). 